\title{
Day by day evolution of a vigorous two wave Saharan dust storm - Thermal and air quality impacts
}

\author{
Konstantinos DIMITRIOU* and Pavlos KASSOMENOS
}

\author{
Laboratory of Meteorology, Department of Physics, University of Ioannina, University Campus, GR-45110, Ioannina, \\ Greece \\ * Corresponding author; email: kdimitriou80@gmail.com
}

Received: August 10, 2016; accepted: January 30, 2018

\begin{abstract}
RESUMEN
En este trabajo se presenta el análisis diario de una intensa tormenta sahariana que afectó a Atenas (Grecia) en abril de 2008 y que constó principalmente de dos oleadas de arena, la primera del 10 al 14 y la segunda del 19 al 22 de ese mes. Se utilizaron datos satelitales diarios (con resolución de $1^{\circ} \times 1^{\circ}$ ) de profundidad óptica de aerosoles (AOD, por sus siglas en inglés) para seguir el curso de las dos columnas de arena originadas en el norte de África a través del Mediterráneo oriental. También se analizaron mediciones superficiales de concentración de partículas $\left(\mathrm{PM}_{10}\right.$ y $\left.\mathrm{PM}_{2.5}\right)$ y parámetros meteorológicos (velocidad y temperatura del aire, humedad relativa y visibilidad). Se consideraron asimismo los intervalos de tiempo antes y después de cada oleada con el fin de identificar la circulación atmosférica que las originó, así como los mecanismos de limpieza que eliminaron la arena africana de la atmósfera ateniense. Mediante las trayectorias inversas de las masas de aire se ubicó el origen de ambas columnas de arena sobre Libia y Túnez, donde se registraron valores diarios extremos de AOD. El transporte de arena en Grecia durante ambas oleadas se asoció con corrientes de aire con dirección sur-oeste, las cuales se atribuyeron a la llegada de sistemas de baja presión del Atlántico. El impacto de ambas columnas de arena en Atenas fue interrumpido por la presencia de un fuerte chorro de aire con dirección del nor-oeste que arrastró las partículas hacia el este a través de Turquía, Chipre y el Oriente Medio. Durante las tormentas de arena, la calidad del aire en Atenas se deterioró de manera importante pero no se registró incomodidad térmica, de acuerdo con las estimaciones de dos índices de contaminación e incomodidad térmica, respectivamente. También se informó disminución de la visibilidad.
\end{abstract}

\begin{abstract}
This paper conducts a day-by-day analysis of an intense Saharan dust storm that struck Athens (Greece) during April 2008 and consisted of two main dust waves (the first from 10/04/2008 to 14/04/2008 and the second from $19 / 04 / 2008$ to $22 / 04 / 2008)$. Daily satellite data $\left(1^{\circ} \times 1^{\circ}\right.$ resolution) of aerosol optical depth (AOD) were used, in order to follow the course of two dust plumes originated in North Africa through the eastern Mediterranean. Ground based measurements of particle concentrations $\left(\mathrm{PM}_{10}\right.$ and $\left.\mathrm{PM}_{2.5}\right)$ and meteorological parameters (wind speed, air temperature, relative humidity and visibility) were also studied. The time intervals before and after each dust wave were taken under consideration, aiming to identify the atmospheric circulation that generated the dust storm and also the clearing mechanisms that removed the African dust from the Athenian atmosphere. Backward air mass trajectories isolated the source of the two dust plumes over Libya and Tunisia, where extreme daily AOD values were recorded. The transportation of dust in the Greek region, during both dust waves, was associated with south westerlies airflows attributed to the advent of low pressure systems from the Atlantic. The impact of both dust waves in Athens was interrupted by the prevalence of a strong north westerlies air stream, which carried the particles eastwards through Turkey, Cyprus and the Middle East. During this dust event, air quality in Athens was severely downgraded, but no thermal discomfort has occurred, according to the estimation of a Pollution Index (PI) and a Discomfort Index (DI), respectively. A drop in visibility was also reported.
\end{abstract}


Keywords: $\mathrm{PM}_{10}, \mathrm{PM}_{2.5}$, aerosol optical depth, Saharan dust, MODIS, Athens.

\section{Introduction}

Multiple outbreaks of Saharan dust in the Mediterranean have been reported in the existing literature: Moroni et al. (2015) identified 22 dust intrusions in Monte Martano (central Italy) in 2009, and estimated the impact of dust on $\mathrm{PM}_{10}$ (particulate matter with aerodynamic diameter less than $10 \mu \mathrm{m}$ ) at 22 $\mu \mathrm{g} \mathrm{m}^{-3}$ per intrusion, whereas the results of Kabatas et al. (2014) suggest a significant contribution of dust to high levels of $\mathrm{PM}_{10}$ in Turkey. The increased composition of crustal elements such as $\mathrm{Ca}, \mathrm{Si}$, Ti, $\mathrm{Mg}$ and $\mathrm{Fe}$ in surface PM concentrations is indicative of the Saharan dust influence (Sprovieri et al., 2011; Marconi et al., 2014; Dimitriou et al., 2015; Malaguti et al., 2015), whereas the exact potential source areas of dust aerosol loadings are usually isolated with an analysis of backward air mass trajectories (Bouchlaghem et al., 2009; Kopanakis et al., 2012; Dimitriou, 2015). The occurrence of African dust outbreaks in the Mediterranean is mainly during spring, summer and early autumn (Papayannis et al., 2009; de Meij and Lelieveld, 2011; Sprovieri et al., 2011; Ciardini et al., 2012; Varga et al., 2014) when the thermal convective activity forces the injection of particles to higher atmospheric levels (Varga et al., 2014).

Only a few former studies have evaluated the associations of airborne desert dust with adverse health effects, however possible impacts were emerged. On Saharan dust days, the findings of Jiménez et al. (2010) and Sajani et al. (2011) suggest increased mortality among the elderly (over 75 yrs. old) in Madrid (Spain) and Emiglia-Romagna (Italy), respectively. Another analysis conducted in Madrid during desert dust outbreaks (Tobías et al., 2011) indicated stronger adverse health effects attributed to PM $\mathrm{COARSE}_{\text {(particulate matter with }}$ aerodynamic diameter from 2.5 to $10 \mu \mathrm{m}$ ), a PM size fraction dominated by particles of natural origin (e.g., dust, sea spray, pollen, etc.) (Koçak et al., 2007; Minguillon et al., 2014). The findings of Pérez et al. (2012) showed that the effects of short-term exposure to PM during Saharan dust days are associated with both cardiovascular and respiratory mortality in Barcelona (Spain), whereas
Malone et al. (2011) found evidence of effects of $\mathrm{PM}_{\mathrm{COARSE}}$ and $\mathrm{PM}_{10}$ on cardiac mortality in Rome (Italy). Finally, in cases of dust episodes in Athens (Greece), the amounts of mineral dust deposited along the human lung are comparable to those received during exposure to heavily polluted urban or smoking areas (Mitsakou et al., 2008), while emergency hospital admissions for pediatric asthma are expected (Samoli et al., 2011).

The atmosphere of the urban area of Athens (Greece) is affected by a mixture of particles emitted from natural and anthropogenic sources (Papayannis et al., 2012). Nevertheless, the impact of Saharan dust has been clearly identified in various previous publications (Kaskaoutis et al., 2008; Papayannis et al., 2009, 2012; Remoundaki et al., 2011; Dimitriou et al., 2015). Dust episodes in Athens are mainly provoked by air masses arriving from South West directions (Papayannis et al., 2005; Remoundaki et al., 2011; Kaskaoutis et al., 2012; Kassomenos et al., 2012), having absorbed significant amounts of dust from North Africa. This atmospheric circulation is usually triggered by low pressure systems approaching from the west, thus bringing desert air masses from the south (Kaskaoutis et al., 2012; Nastos, 2012). Under the desert dust influence, $\mathrm{PM}_{10}$ in Athens are mostly constituted by the coarse aerosol fraction (Kassomenos et al., 2012; Pateraki et al., 2013).

This paper conducts a day-by-day analysis (Lee et al., 2013) of an intense Saharan dust storm, which struck Athens during April 2008, consisted from two main dust waves. The time intervals before and after each dust wave were also studied, in order to determine the types of atmospheric circulation which caused this intense dust episode and also the processes which removed the dust aerosol from the Athenian atmosphere, based on air mass trajectories and synoptic charts. Satellite observations of aerosol optical depth (AOD) were used in order to identify the generation of dust plumes and follow their course across Greece. The AOD values were also combined with ground based measurements of PM and meteorological parameters, aiming to evaluate the impact of the incoming North African air parcels to air quality and thermal comfort conditions. 


\section{Data and methodology}

\subsection{Data}

\subsubsection{Ground based air pollution data}

Athens is the capital city of Greece with approximately 5000000 inhabitants and thus incorporates almost $50 \%$ of the country's total population. The city's public air quality monitoring network is supervised by the Greek Ministry of Environment and Energy and includes 22 urban and suburban stations with traffic, background and industrial characteristics. For this paper, ground based measurements of $\mathrm{PM}_{10}$, $\mathrm{PM}_{2.5}$ (particulate matter with aerodynamic diameter less than $2.5 \mu \mathrm{m}$ ) and $\mathrm{NO}_{2}$ daily average concentrations were obtained from the suburban background monitoring station of Agia Paraskevi (AGP), located in the northeast (NE) boundaries of the Athens basin (lat. 38.00, long. 23.82, alt. 290 m) (Fig. 1a). The available hourly concentrations of $\mathrm{NO}_{2}$ were also used. Due to the absence of direct combustion emissions (e.g., traffic, industrial, etc.) in the vicinity of AGP station, the selected sampling site was considered as ideal for the identification of atmospheric long-range transport influences, in contrast with central heavily trafficked sites. This study is focused on the AGP station, where $\mathrm{PM}_{2.5}$ measurements are performed, yet $\mathrm{PM}_{10}$ daily concentrations from the suburban background monitoring station in Thrakomakedones (THR) (lat. 38.14, long. 23.76, alt. 550 m) (Fig. 1a) were also used in order to verify our findings and also to provide additional information concerning the spatial distribution of exogenous material over
Athens. All data were downloaded from the website (http://www.eea.europa.eu) of the European Environment Agency (station codes: GR0039A [AGP], GR0037A [THR]). PM measurements were performed with Thermo Andersen ESM FH 62 I-R beta ray attenuation scanning devices, whereas $\mathrm{NO}_{2}$ monitoring was carried out with a chemiluminescence analyzer (Horiba model APNA 360).

\subsubsection{Satellite AOD data}

For the detection of possible aerosol intrusions in Athens, Greece from transboundary sources, daily AOD (dimensionless) values at $550 \mathrm{~nm}$ were also used. These AOD measurements are included in the product Collection 5.1 (level 3) of the Moderate Resolution Imaging Spectroradiometer (MODIS) system, carried aboard the Terra satellite of the National Aeronautics and Space Administration (NASA). During the studied period (06/04/200826/04/2008), Terra satellite overpassed the Eastern Mediterranean around 09:30 and 20:30 UTC. Daily AOD data are derived on a $1^{\circ} \times 1^{\circ}$ resolution grid and were downloaded from NASA's portal Giovanni (http://giovanni.sci.gsfc.nasa.gov).

\subsubsection{Meteorological data}

For the needs of this work, average daily values of wind speed (knots), air temperature (F), dew point temperature (F) and visibility (miles) were obtained from a meteorological station situated $20 \mathrm{~km}$ away from the city center to the west (lat. 38.06, long. a)

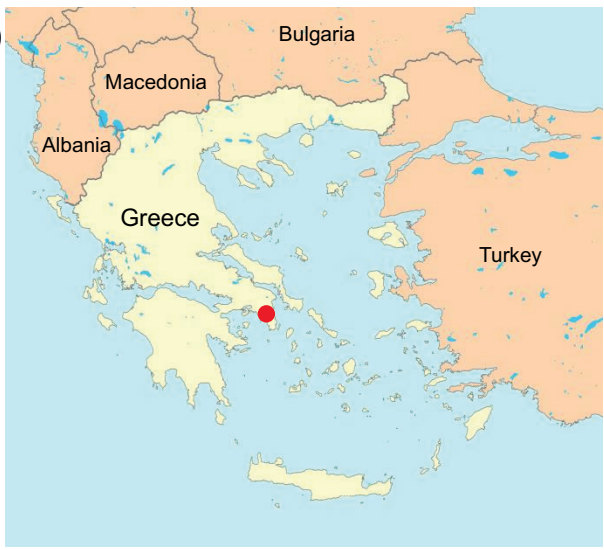

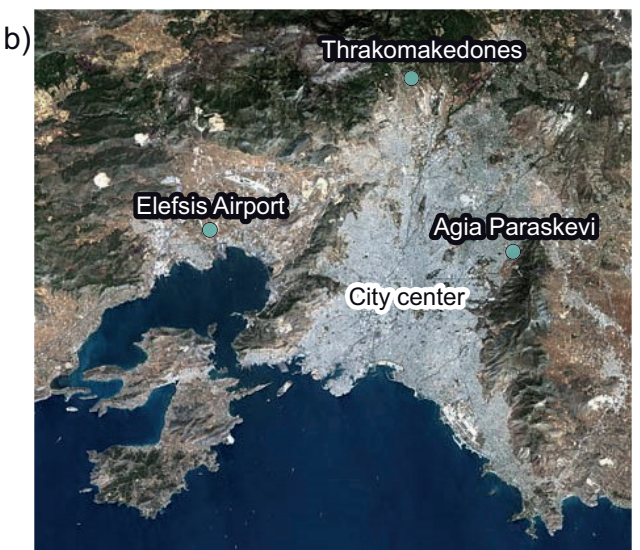

Fig. 1. (a) Map of Greece. The red dot marks the location of the city of Athens. (b) Map of the broader Athens basin. The blue dots mark the exact positions of the air pollution (Agia Paraskevi and Thrakomakedones) and the meteorological (Elefsis airport) monitoring stations. 
23.93, alt. $43.6 \mathrm{~m}$ ), in the airport of Elefsis (Fig. 1a). All the meteorological parameters were acquired from the website (https://www.ncdc.noaa.gov/isd/ data-access) of the National Centers for Environmental Information (NCEI) of the National Oceanic and Atmospheric Administration (NOAA). Air temperature and dew point temperature were used in order to calculate relative humidity $(\mathrm{RH})$ values $(\%)$ based on (1), where vapor pressure (E) and saturation vapor pressure $\left(E_{s}\right)$ were calculated according to an approximation of the Clausius-Clapeyron equation reflected in (2) and (3) (https://iridl.ldeo.columbia. edu/dochelp/QA/Basic/dewpoint.html).

$$
\begin{aligned}
& R H=100 \% \cdot \frac{E}{E_{s}} \\
& E=E_{0} \cdot \exp \left[\left(\frac{L}{R_{V}}\right) \cdot\left(\frac{1}{T_{0}}-\frac{1}{T_{d}}\right)\right] \\
& E_{s}=E_{0} \cdot \exp \left[\left(\frac{L}{R_{V}}\right) \cdot\left(\frac{1}{T_{0}}-\frac{1}{T}\right)\right]
\end{aligned}
$$

The included parameters in (2) and (3) are $E_{0}=$ $0.611 \mathrm{kPa} ;(L / R V)=5423 \mathrm{~K}$, and $T_{0}=273 \mathrm{~K}$. $T$ is air temperature $(\mathrm{K})$ and $T d$ is dew point temperature (K). Finally, for the presentation of this paper, the units of wind speed, air temperature, and visibility were changed to $\mathrm{m} \mathrm{sec}^{-1}, \mathrm{C}$, and $\mathrm{km}$, respectively.

\subsection{Methodology}

2.2.1 Day by day analysis of an intense dust storm Firstly, for the identification of possible Saharan dust intrusions in Athens, Greece, daily $\mathrm{PM}_{10}$ concentrations recorded at AGP were studied for the detection of consecutive (at least three days) exceedances of the daily $\mathrm{PM}_{10}$ limit $\left(50 \mu \mathrm{g} \mathrm{m}^{-3}\right)$ determined by EU regulations. Dust particles are mainly categorized in the $\mathrm{PM}_{\text {COARSE }}$ size fraction (Chen et al., 2013; Dimitriou, 2015; Masmoudi et al., 2015), thus PM $_{\text {COARSE levels }}$ were particularly considered. $\mathrm{NO}_{2}$ concentrations were used as a marker of local combustion emissions. Daily $\mathrm{PM}_{10}$ concentrations in THR were also studied, aiming to indicate the non-local characteristics of the aerosol episodes.

In order to achieve dust aerosol event, a dayby-day observation of a severe two wave (the first from $10 / 04 / 2008$ to $14 / 04 / 2008$ and the second from $19 / 04 / 2008$ to $22 / 04 / 2008$ ) which struck Athens during April 2008, daily AOD values from MODIS were plotted. The $\mathrm{R}$ software was used for visualization purposes. The area of interest for this work extends within 27.0-47.0 N and 10.0-47.0 E. Aiming to fully analyze the evolution of this vigorous dust episode, the four-day time intervals which elapsed among the two dust waves, and also before the first and after the second dust wave, were also studied. Thus, a 21-day period (06/04/2008-26/04/2008) was finally taken under consideration. The Hybrid Single-Particle Lagrangian Integrated Trajectory (HYSPLIT) model (http://www.arl.noaa.gov/HYSPLIT.php) of NOAA, based on NCEP/NCAR global reanalysis meteorological data, was used in order to produce backward air mass trajectories with duration of four days, in order to identify the origin of the air masses carrying the exogenous particles in Athens. Three air mass arrival heights above ground level (AGL) were selected: near ground (500 m AGL), upper boundary layer (1500 m AGL), and free atmosphere (3000 m AGL), whereas the arrival time was set at 12:00 UTC. In addition, maps presenting the geopotential height (tens of meters) of the $500 \mathrm{hPa}$ pressure level along with surface barometric pressure (hPa) were also created by NCEP/NCAR reanalysis data, through the website http://www.wetterzentrale. de/topkarten/fsreaeur.html of the German weather service.

\subsubsection{Thermal stress and air quality indices}

Due to the additional crustal aerosol burden transported into the Athenian atmosphere from North Africa, air quality degradation was expected. In order to evaluate potential health risks for the population due to the increased $\mathrm{PM}_{10}$ concentrations, a daily pollution index (PI) was applied in AGP (Murena, 2004; Kyrkilis et al., 2007; Buchholz et al., 2010; Dimitriou et al., 2013; Li et al., 2014). The PI defines five distinct air quality classes and matches a reference concentration $\left(C_{p}\right)$ of the studied individual pollutant $\left(\mathrm{PM}_{10}, \mathrm{NO}_{2}, \mathrm{SO}_{2}, \mathrm{CO}\right.$ or $\left.\mathrm{O}_{3}\right)$ to one of the five categories (Table I). For $\mathrm{PM}_{10}, C_{p}$ is the daily average concentration. The PI is expressed by (4):

$\mathrm{PI}=\frac{P I_{h i}-P I_{l o}}{B P_{h i}-B P_{l o}}\left(C_{p}-B P_{l o}\right)+P I_{l o}$

where $B P_{h i}$ and $B P_{l o}$ are the upper and lower concentration breakpoints respectively of the PI category 
Table I. $C_{p}$ concentration breakpoints $\left(\mu \mathrm{g} \mathrm{m}^{-3}\right)$ and corresponding pollution index (PI) values, for each PI air quality category ${ }^{\mathrm{a}}$ (Murena, 2004).

\begin{tabular}{lrcc}
\hline Pollution category & PI & $\begin{array}{c}\mathrm{PM}_{10} 24 \mathrm{~h}_{\text {average }}\left(\mu \mathrm{g} \mathrm{m}^{-3}\right) \\
\text { Unhealthy }\end{array}$ & $\begin{array}{r}\mathrm{NO}_{2} 24 \mathrm{~h} \text { maximum } \\
\left(\mu \mathrm{g} \mathrm{m}^{-3}\right)\end{array}$ \\
Unhealthy for sensitive groups & 85 & 500 & 1900 \\
Moderate pollution & 70 & 144 & 950 \\
Low pollution & 50 & 50 & 400 \\
Good quality & 25 & 20 & 200 \\
\hline
\end{tabular}

${ }^{\text {a }}$ For the good quality category, $B \mathrm{P}_{l o}\left(\mu \mathrm{g} \mathrm{m}^{-3}\right)$ and $P I_{l o}$ (dimensionless) values are equal to zero.

in which $C_{p}$ corresponds, and $P I_{h i}$ and $P I_{\mathrm{lo}}$ are the upper and lower PI breakpoints of the same category respectively (Table I). Daily PI was also applied for $\mathrm{NO}_{2}$, for which $C_{p}$ is the maximum hourly concentration of the studied day.

The incoming air masses of North African origin, besides the transfer of particulates, may also provoke radical variations in temperature and $\mathrm{RH}$ levels, inducing thermal stress. For that reason, a simple discomfort index (DI) (Thom, 1959) was implemented in order to estimate the environmental heat stress and the correlated thermal sensation, according to the DI classes described in Table II. The DI was calculated according to (5) (Giles et al., 1990; Mavrakis et al., 2012):

$$
D I=T-0.55(1-0.01 R H)(T-14.5)
$$

in which $T$ is the average daily air temperature (C) and $R H$ is the average daily relative humidity (\%).

Table II. DI breakpoint values and expected heat stress assessment (Mavrakis et al., 2012).

\begin{tabular}{ll}
\hline DI values & Expected heat stress \\
\hline $26.7<$ DI & $\begin{array}{l}\text { Discomfort is considerably high and } \\
\text { hazardous } \\
100 \% \text { of the population experiences } \\
\text { discomfort }\end{array}$ \\
$24 \leq$ DI & $\begin{array}{l}50 \% \text { of the population experiences } \\
\text { discomfort }\end{array}$ \\
$21 \leq$ DI $<24$ & $\begin{array}{l}10 \% \text { of the population experiences } \\
\text { discomfort }\end{array}$ \\
$18 \leq$ DI $<21$ & Thermal comfort \\
\hline
\end{tabular}

\section{Results}

\subsection{Variations of PM concentrations}

Intense variations of PM concentrations were recorded at AGP during the studied 21-day time interval (Fig. 2). Daily average $\mathrm{PM}_{10}$ levels exceeded the daily limit of $50 \mu \mathrm{g} \mathrm{m}^{-3}$ from 10/04/2008-14/04/2008 and also from 19/04/2008-22/04/2008, however extreme concentrations of $\mathrm{PM}_{10}$ were particularly indicated during $12\left(114 \mu \mathrm{g} \mathrm{m}^{-3}\right), 13\left(124 \mu \mathrm{g} \mathrm{m}^{-3}\right), 14\left(127 \mu \mathrm{g} \mathrm{m}^{-3}\right)$, $21\left(110 \mu \mathrm{g} \mathrm{m}^{-3}\right)$, and 22/04/2008 (109 $\left.\mathrm{g} \mathrm{m}^{-3}\right)$. These highly increased concentrations were primarily attributed to the increment of $\mathrm{PM}_{\mathrm{COARSE}}$ levels (e.g., dust, pollen), as it was clearly deduced from a drop of $\mathrm{PM}_{2.5} / \mathrm{PM}_{10}(\%)$ fraction (Fig. 2). In addition, $\mathrm{PM}_{2.5}$ levels were only slightly enhanced during the episodic days. Similar variations of $\mathrm{PM}_{10}$ levels and extreme $\mathrm{PM}_{10}$ concentrations, were also detected in THR during the same period (Fig. 2), hence long range transport impacts were suggested. $\mathrm{NO}_{2}$ was considered as a marker of local combustion emissions and thus, weak variations of $\mathrm{NO}_{2}$ levels, observed during the whole studied period (Fig. 2), strongly disconnected the extreme aerosol loadings from local anthropogenic PM sources.

\subsection{Day by day observation of $A O D$ values and at- mospheric circulation \\ 3.2.1 Time interval before the first dust wave (06/04/2008-09/04/2008)}

Air mass trajectories ending in Athens at 06/04/2008 and $07 / 04 / 08$ indicate the city was affected by a north-west (NW) airflow (Fig. 3a) attributed to a deep depression located at the North Sea area (Fig. 3b). However, during 08/4/2008 and primarily 09/04/08, due to the advent of a low pressure system from the 


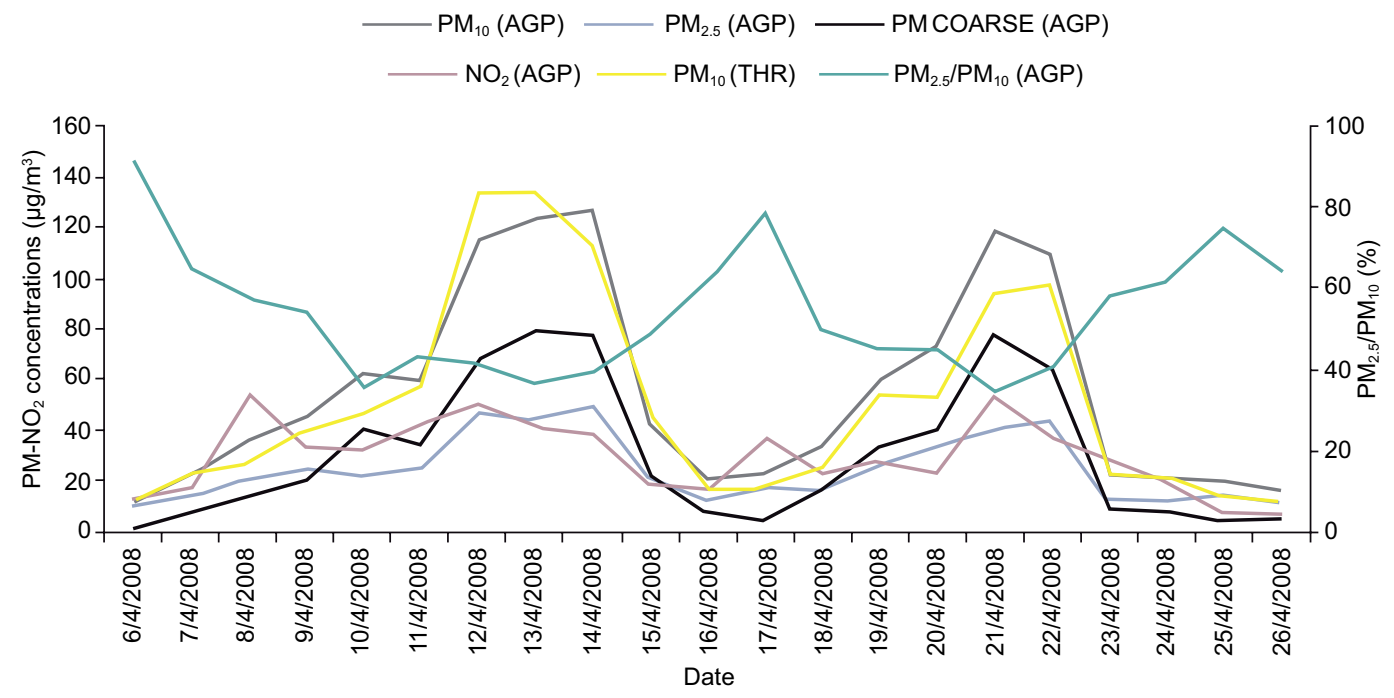

Fig. 2. Variations of $\mathrm{PM}-\mathrm{NO}_{2}$ concentrations $\left(\mu \mathrm{g} \mathrm{m}^{-3}\right)$ and $\mathrm{PM}_{2.5} / \mathrm{PM}_{10}$ fraction (\%) during the time interval 06/04/2008-26/04/2008 in AGP and THR.

mid-Atlantic to West Europe, air parcels possibly enriched with dust aerosols approached Athens from south west (SW) directions (Fig. 3a). This hypothesis was verified by AOD observations of MODIS (Fig. 4) indicating a dust plume from Libya and Tunisia moving towards Greece (Fig. 4c, d, e). The initial effect of incoming dust was recorded at AGP during 09/04/2008, when the average daily $\mathrm{PM}_{10}$ concentration was $46 \mu \mathrm{g} \mathrm{m}^{-3}$ (Fig. 2).

\subsubsection{First dust wave (10/04/2008-14/04/2008)}

During the time interval 10/04/2008-14/04/2008, the eastward movement of the barometric depression, crossing the Iberian Peninsula and the western Mediterranean (Fig. 5b), progressively generated a south-southwest (S-SW) airflow (Fig. 5a), influencing the city of Athens (Nastos, 2012). The transport of dust aerosols from Libya and Tunisia to Athens (Marconi et al., 2014) through the Mediterranean, was successfully identified by MODIS observations showing a gradual increase of AOD in the Greek region (Fig. 6). Throughout this first fiveday dust wave, $\mathrm{PM}_{10}$ concentrations in AGP were over the EU daily standards, however the effect of dust was particularly indicated in AGP and THR from 12/04/2008-14/04/2008 (Figs. 2, 6), when the air mass trajectories reached Athens from more southern directions, overflying above Tunisia and Libya (Fig. 5a). Despite the highly elevated AOD values and $\mathrm{PM}_{10}$ concentrations during 14/04/2008 in the area of Athens, a removal of dust to the east was detected from MODIS measurements, towards Turkey and the Middle East (Fig. 6e).

\subsubsection{Time interval between the two dust waves (15/04/2008 - 18/04/2008)}

After the passing of the first large low-pressure system over SW Europe (Fig. 7b), Athens was affected by NW long-range atmospheric trajectories (Fig. 7a). This NW airstream transfers the Saharan dust to the east, mainly through Turkey and Cyprus where increased AOD levels were observed from 15/04/2008 to $16 / 04 / 2008$ (Fig. 8a, b). However, a new deep depression ( $980 \mathrm{hPa}$ low pressure center), initially located to the south of Greenland (15/04/2008) (Fig. 7b), progressively approaches the NW coast of the Iberian Peninsula (Fig. 7b). Thus, the air parcels are gradually arriving in Athens from SW directions (mainly on 18/04/2008) (Fig. 7a) and the atmospheric mechanism that provoked the first dust wave tends to be repeated. Moreover, the strongly enhanced AOD values recorded over coastal Libya and Tunisia during 17/04/2008 and 18/04/2008 (Fig. 8c, d) suggest the outbreak of a new dust plume.

\subsubsection{Second dust wave (19/04/2008-22/04/2008)}

From $19 / 04 / 2008$ to $22 / 04 / 2008$, due to the eastward movement of the second barometric depression 
a)
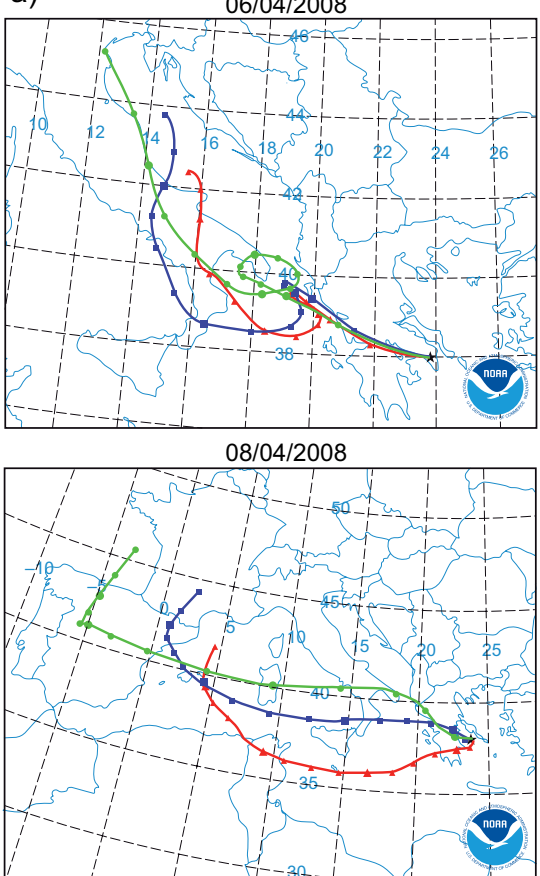

b) $\quad 06 / 04 / 2008$

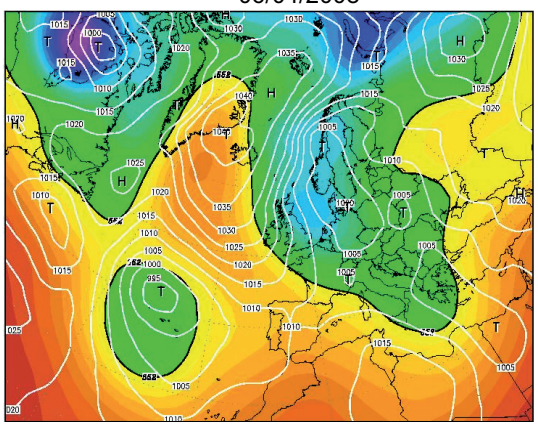

$08 / 04 / 2008$

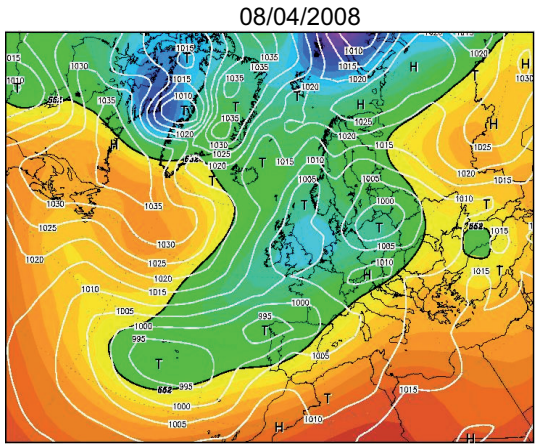

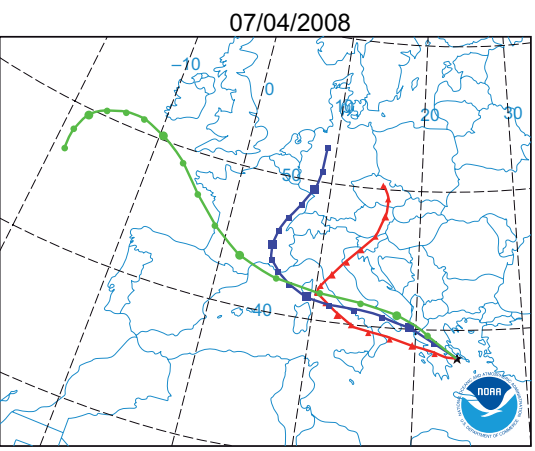

$09 / 04 / 2008$

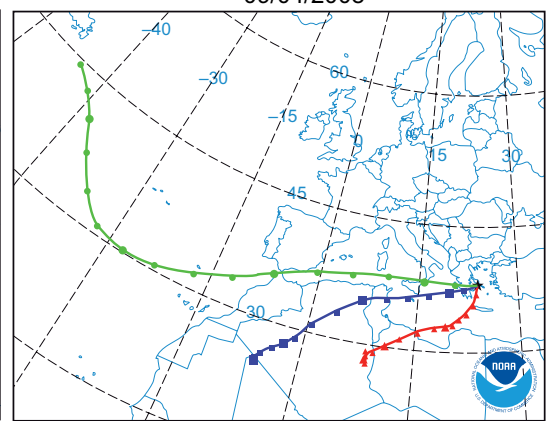

$07 / 04 / 2008$

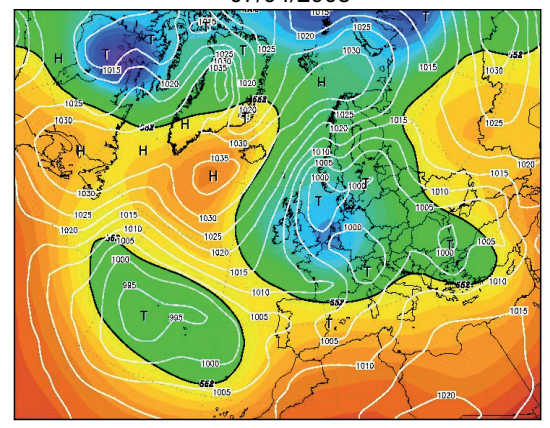

09/04/2008

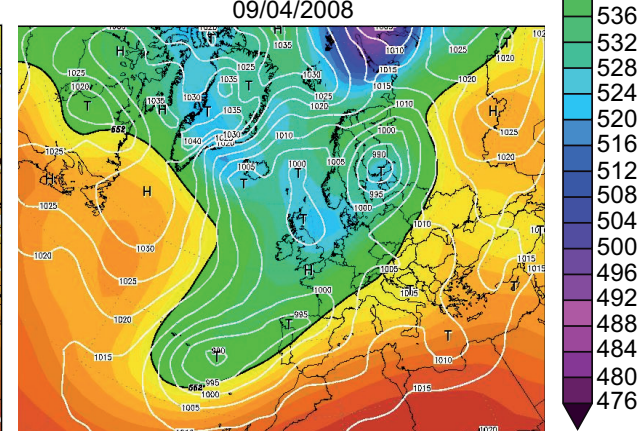

Fig. 3. (a) Air mass trajectories arriving over Athens at $500 \mathrm{~m}$ AGL (red), $1500 \mathrm{~m}$ AGL (blue) and $3000 \mathrm{~m}$ AGL (green). (b) Geopotential height (tens of meters) of the $500 \mathrm{hPa}$ pressure level along with surface barometric pressure (hPa). All maps refer to the time interval 06/04/2008-09/04/2008. 
a)

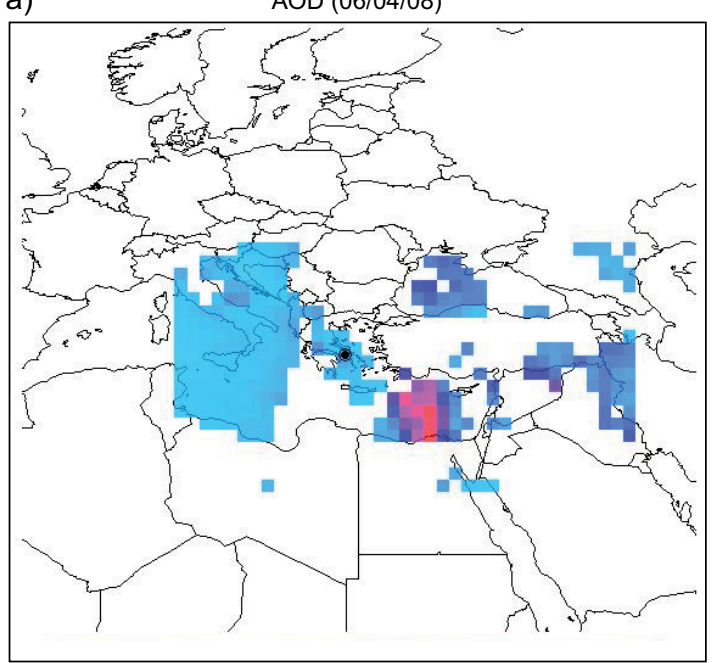

c)

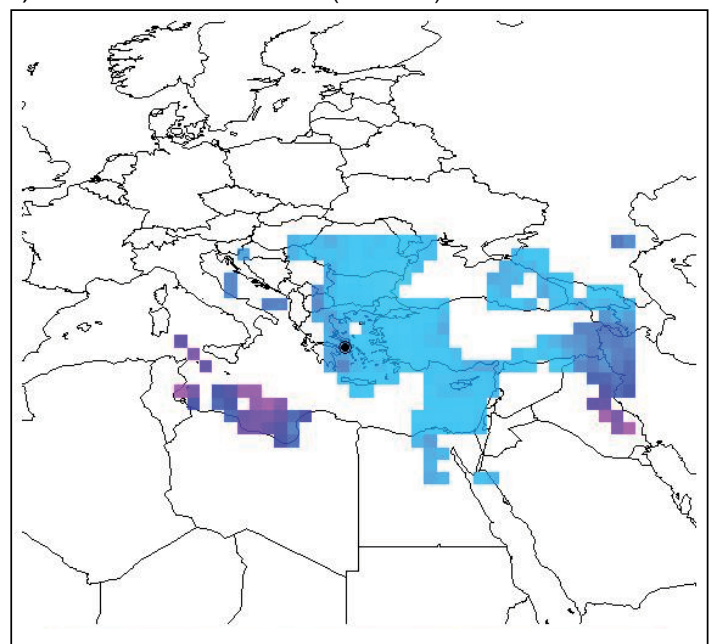

b)

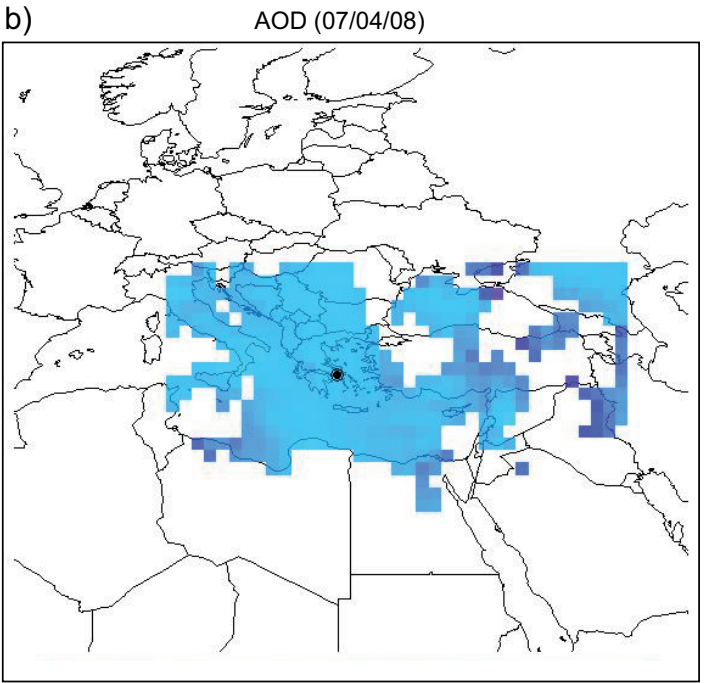

d)

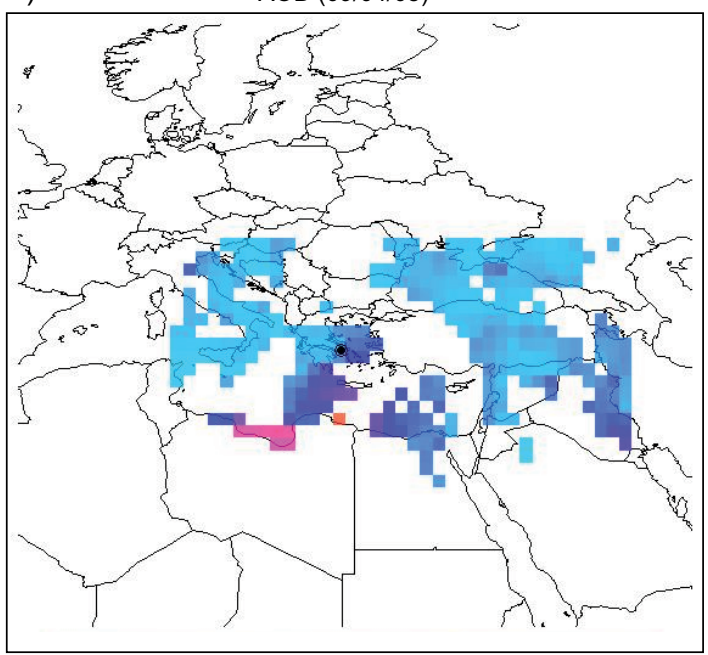

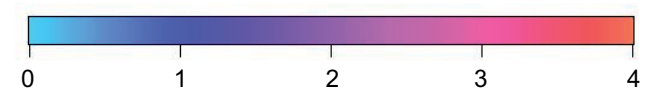

e)

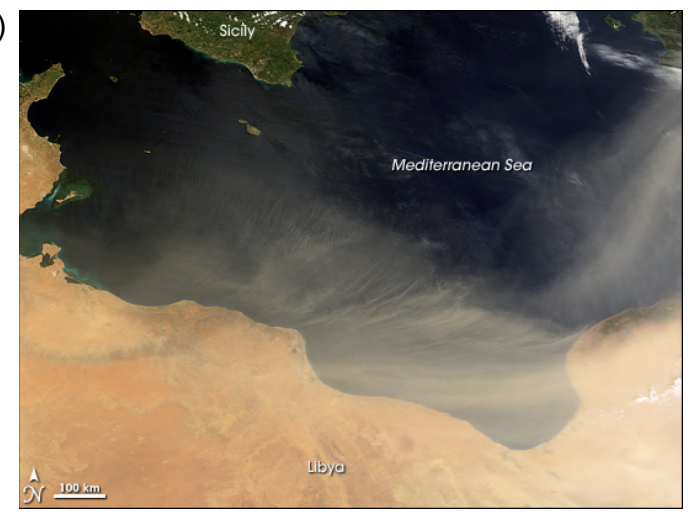

Fig. 4. (a-d) Daily AOD observations of MODIS from 06/04/2008 to 09/04/2008. (e) A Saharan dust plume recorded from MODIS sensor over Libya during 9/4/2008. 
a)

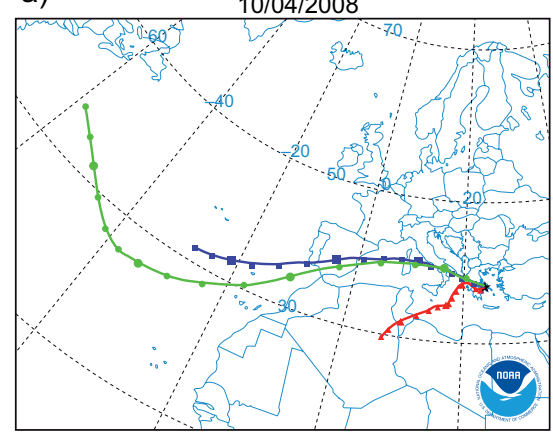

$11 / 04 / 2008$

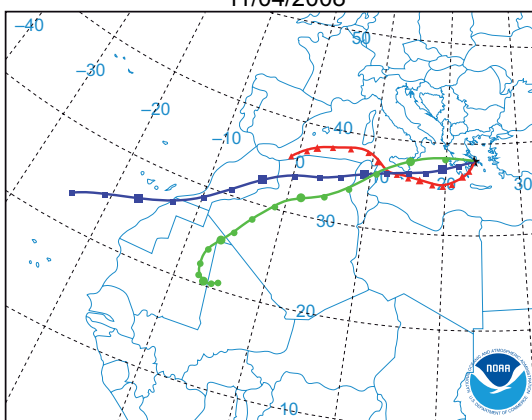

$13 / 04 / 2008$

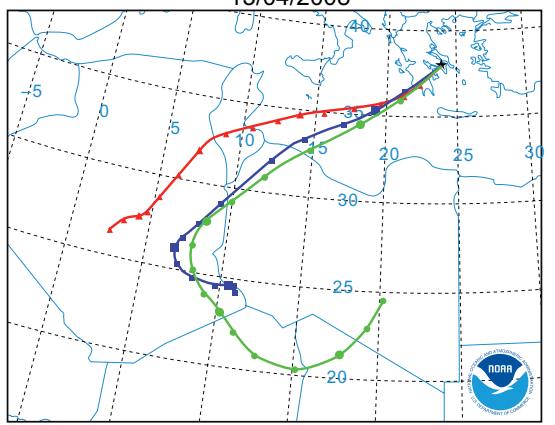

b)
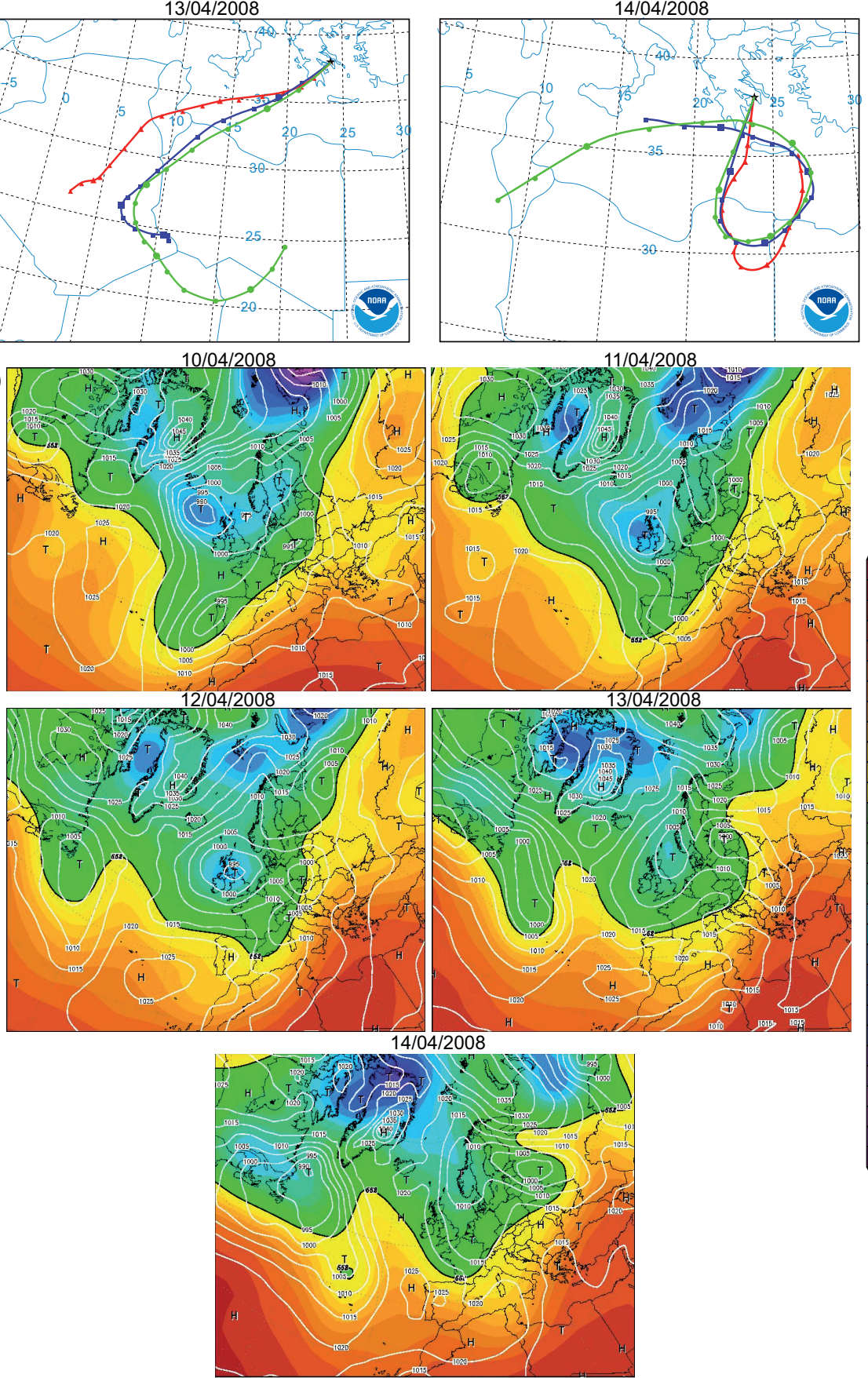

Fig. 5. Same as in Figure 3, but for the time interval 10/04/2008-14/04/2008. 
a)

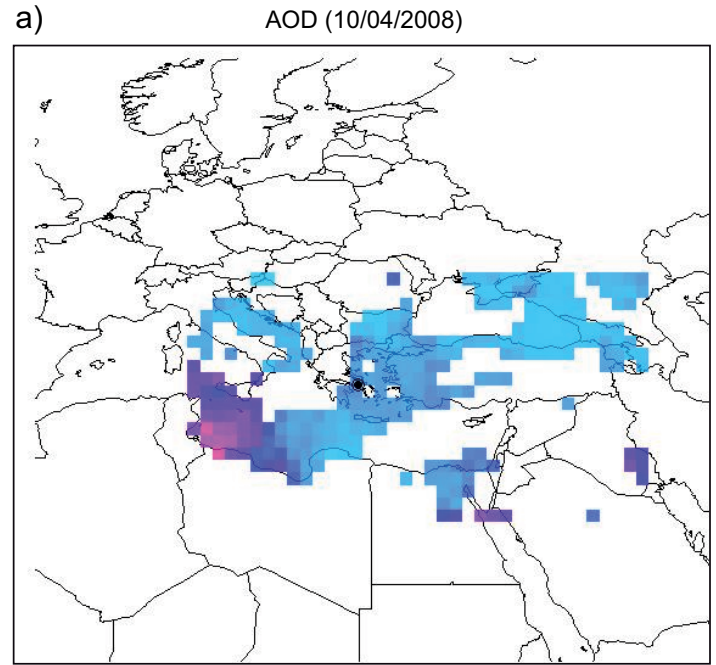

c)

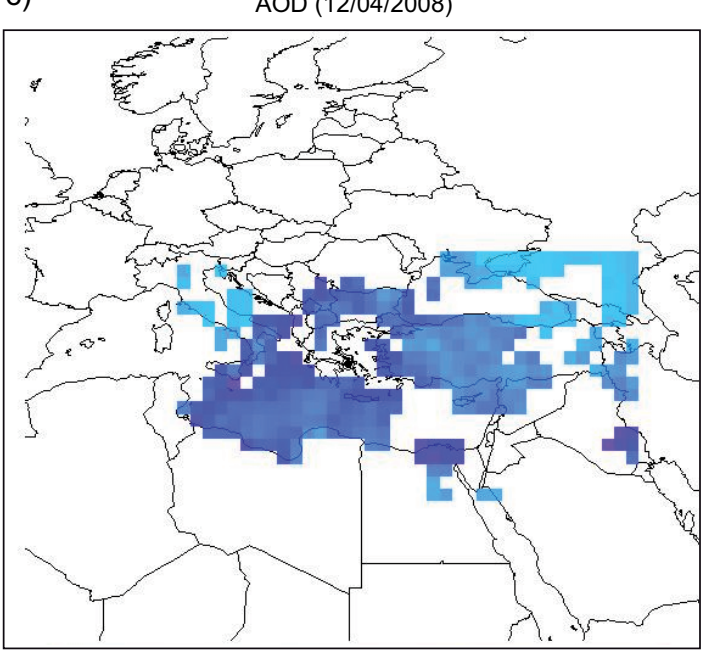

e)

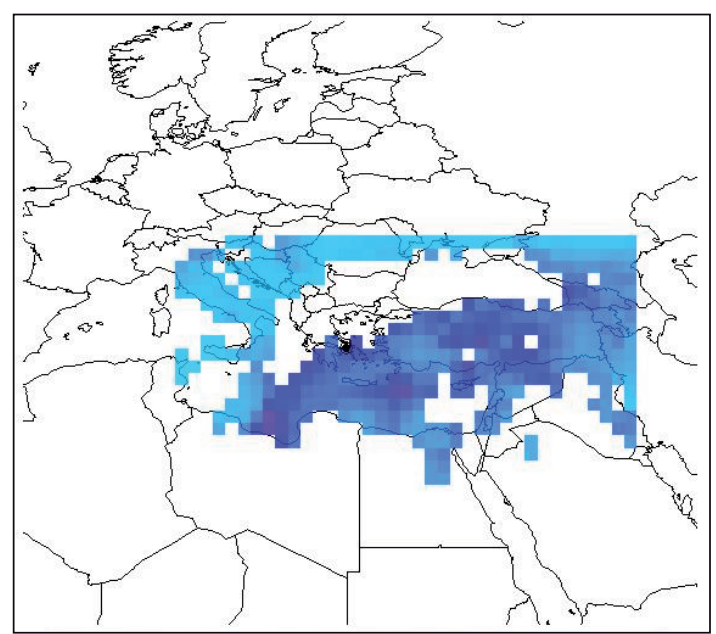

b)

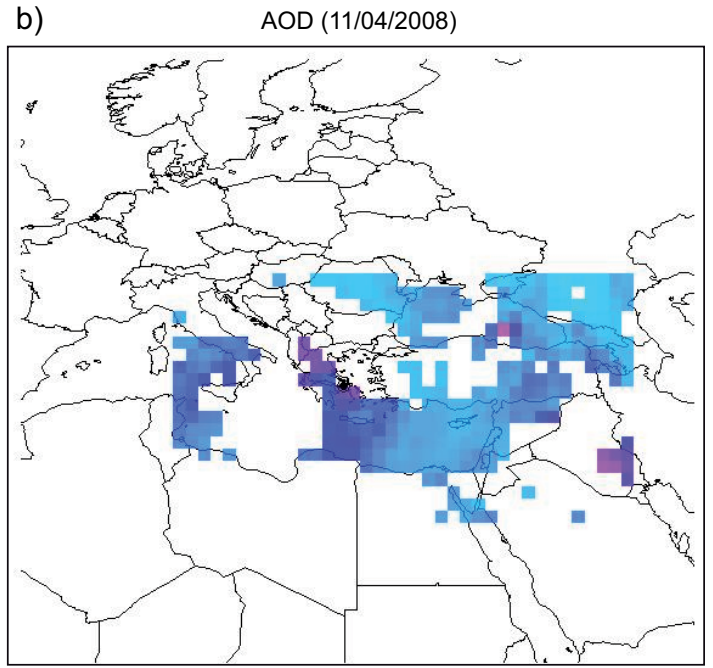

d)

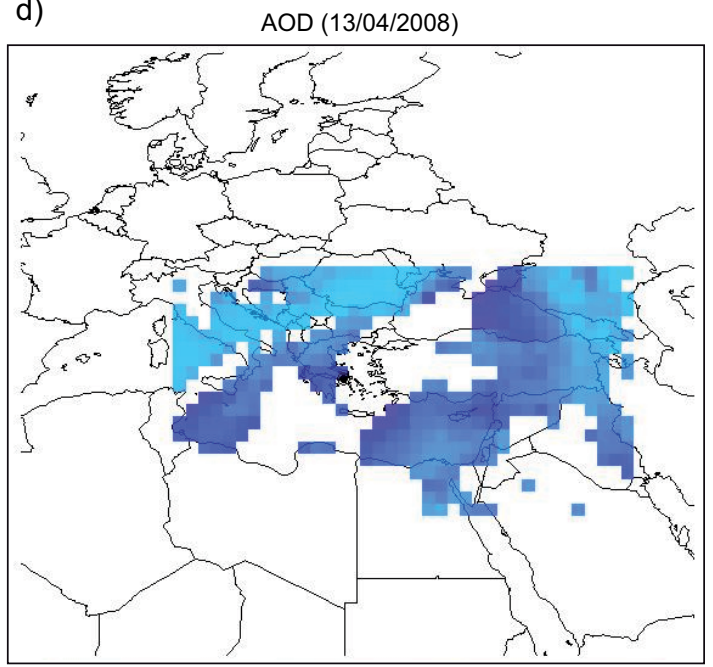

Fig. 6. Daily AOD observations of MODIS from 10/04/2008 to 14/04/2008. 
a)
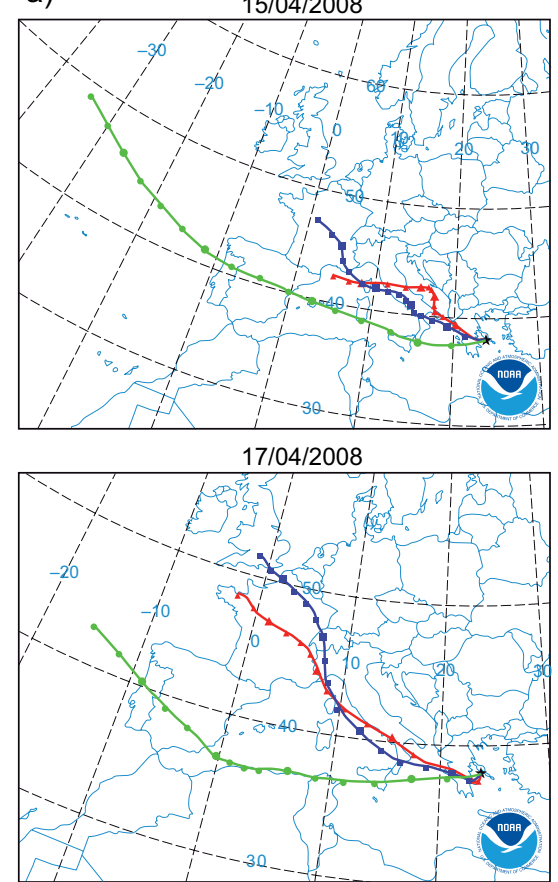

b)

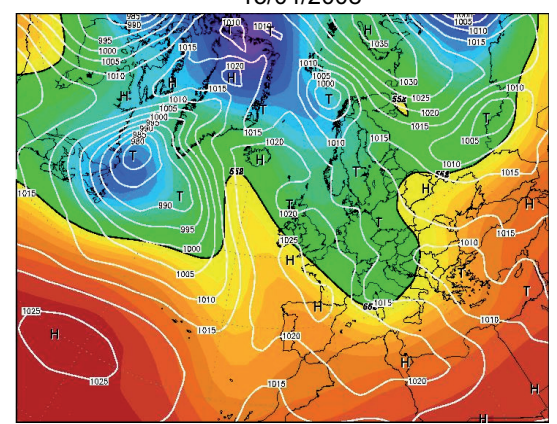

17/04/2008

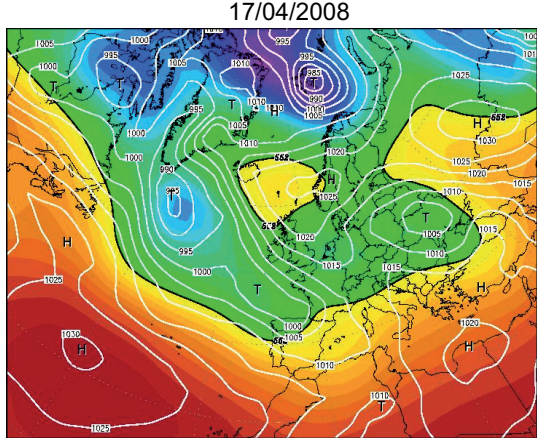

$16 / 04 / 2008$

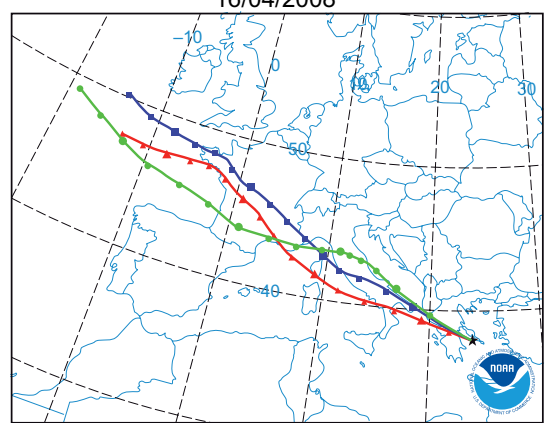

18/04/2008

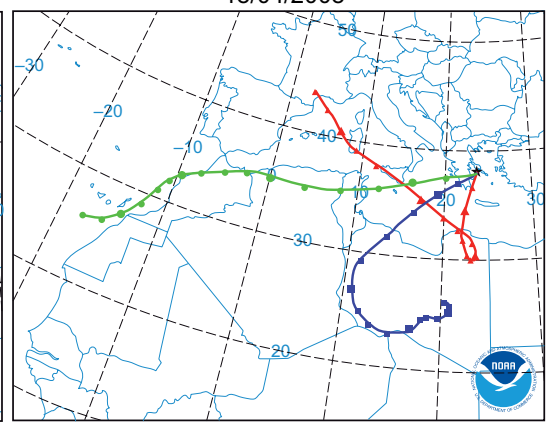

$16 / 04 / 2008$

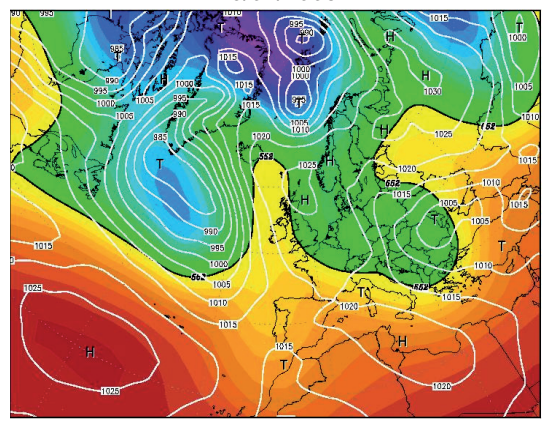

$18 / 04 / 2008$

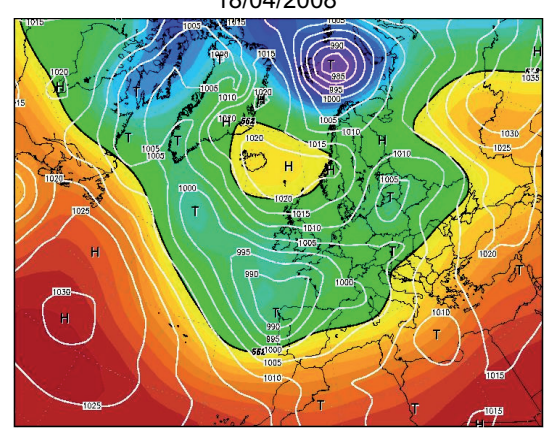

Fig. 7. Same as in Figure 3, but for the time interval 15/04/2008-18/04/2008. 
a)

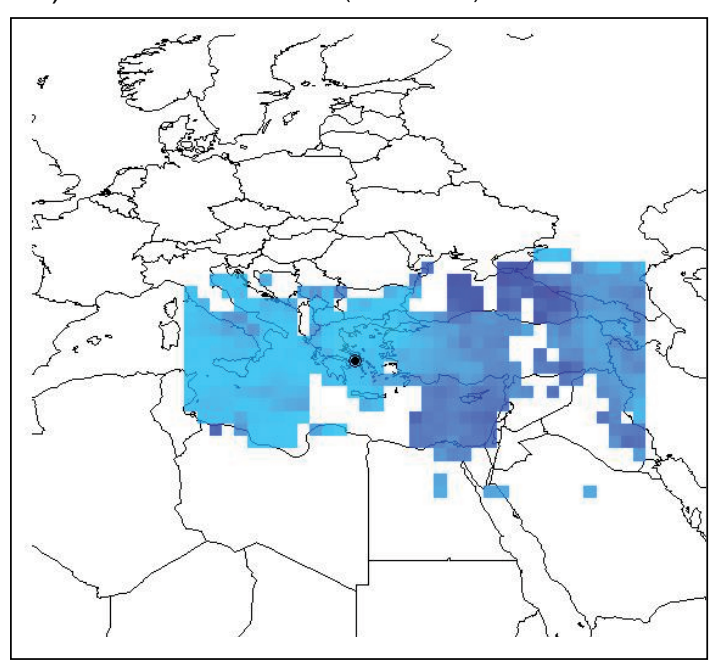

c)

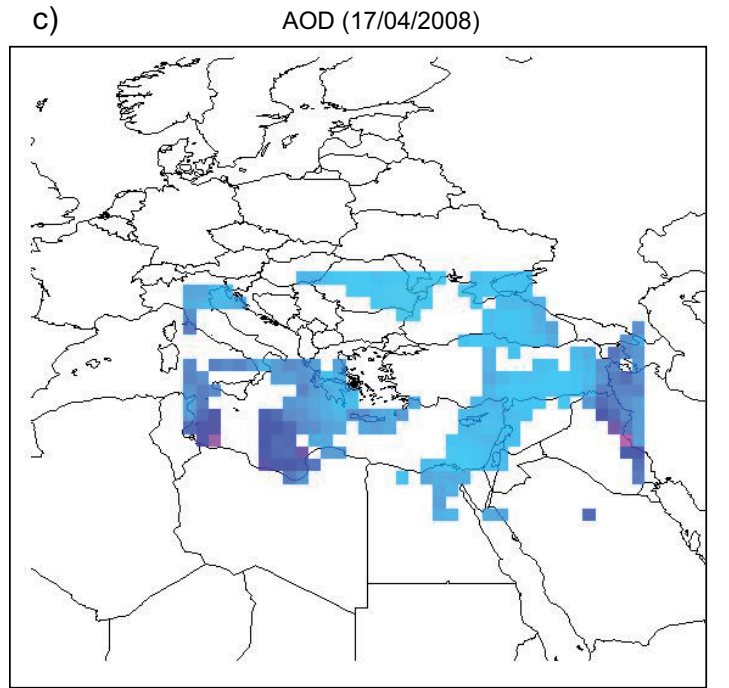

b)

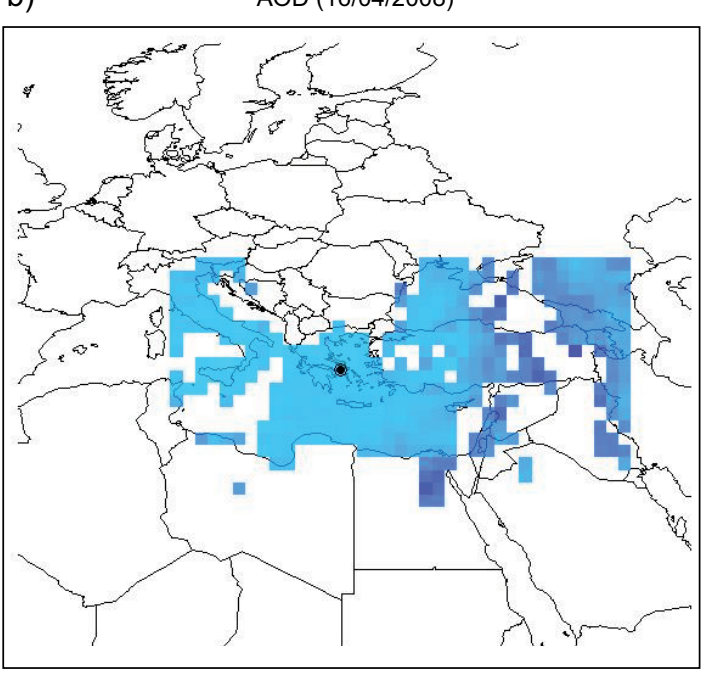

d)
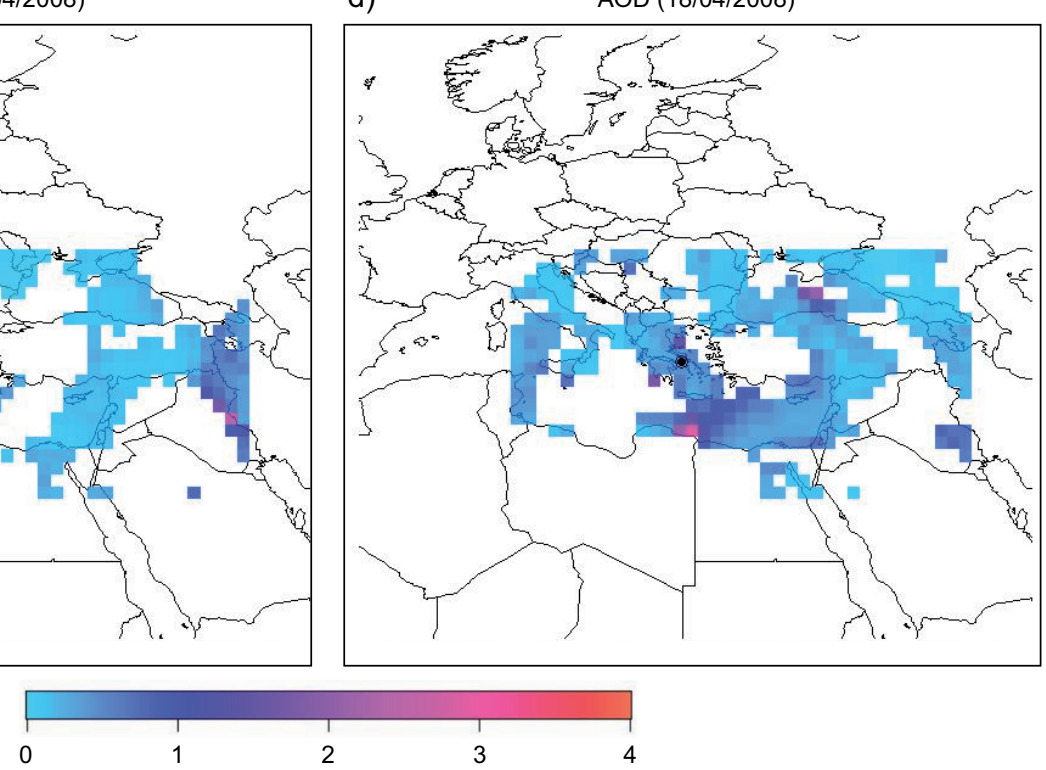

Fig. 8. Daily AOD observations of MODIS from 15/04/2008 to 18/04/2008.

(Fig. 9b) overpassing the Iberian Peninsula and the western Mediterranean, air mass trajectories are reaching Athens from SW directions through NW Africa (Fig. 9a). As with the previous dust wave, this specific type of atmospheric circulation was also associated with the inflow of a second dust intrusion in Athens, responsible of highly raised concentrations of $\mathrm{PM}_{10}$ in AGP and THR (Fig. 2). The advent of dust was verified by MODIS observations, indicating increased AOD levels in the Greek region (Fig. 10).
3.2.5 Time interval after the second dust wave (23/04/2008-26/04/2008)

After inducing the last dust wave, the second low-pressure system travelled across Europe to the northeast (Fig. 11b), affecting Athens during 23/04/2008 and 24/04/2008 (Fig. 11a). This air stream gradually clears the Athenian atmosphere by transferring the Saharan dust to the southeast (SE), reducing $\mathrm{PM}_{10}$ concentrations in AGP and THR (Fig. 2). A distinguishable dust zone was 
a)
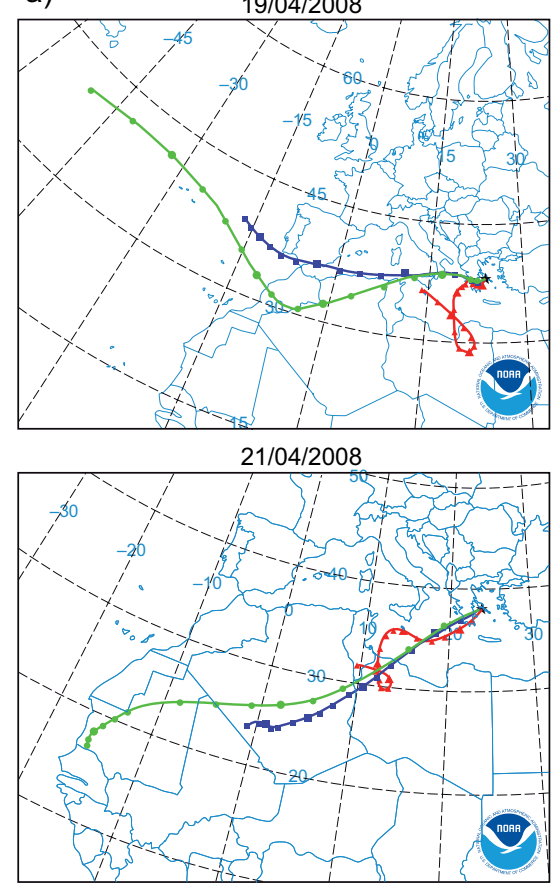

b)

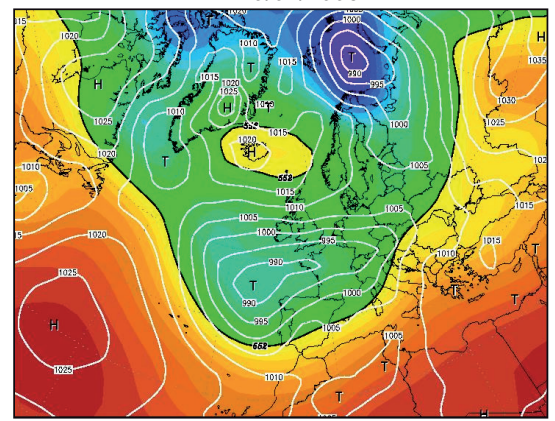

$21 / 04 / 2008$

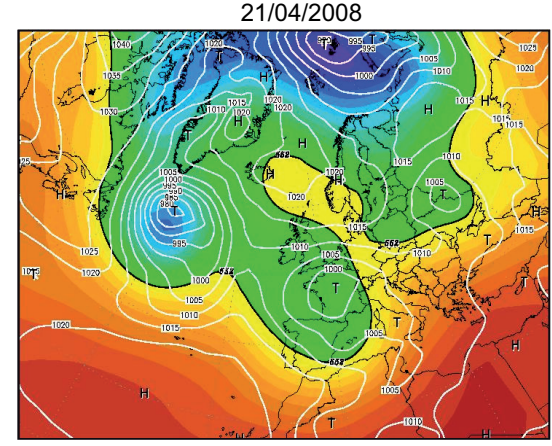

Fig. 9. Same as in Figure 3, but for the time interval 19/04/2008-22/04/2008.
$20 / 04 / 2008$

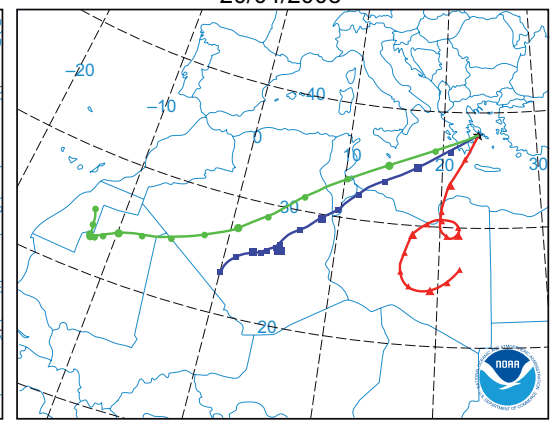

$22 / 04 / 2008$

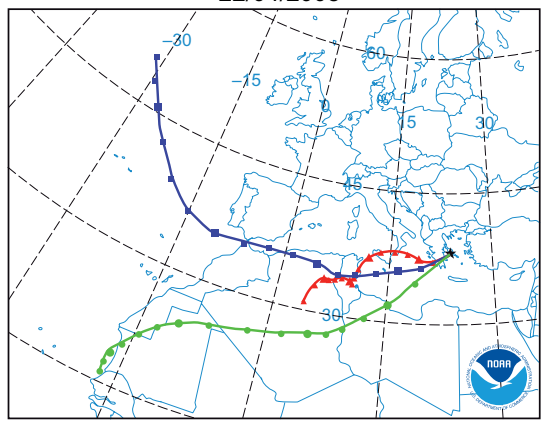

$20 / 04 / 2008$

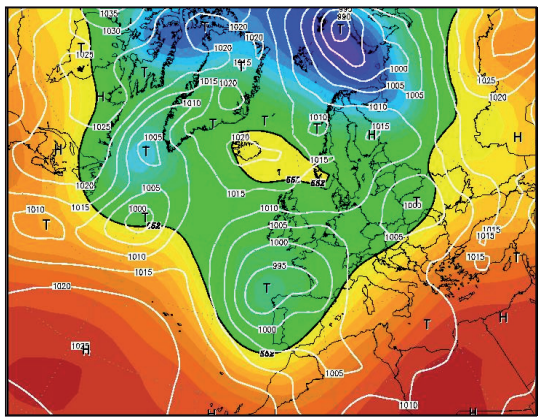

$22 / 04 / 2008$
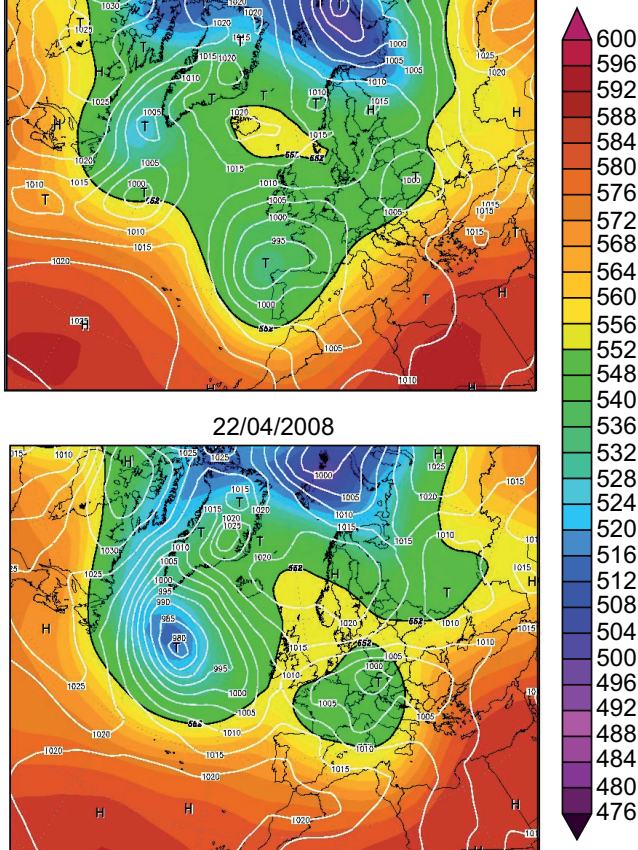
a)

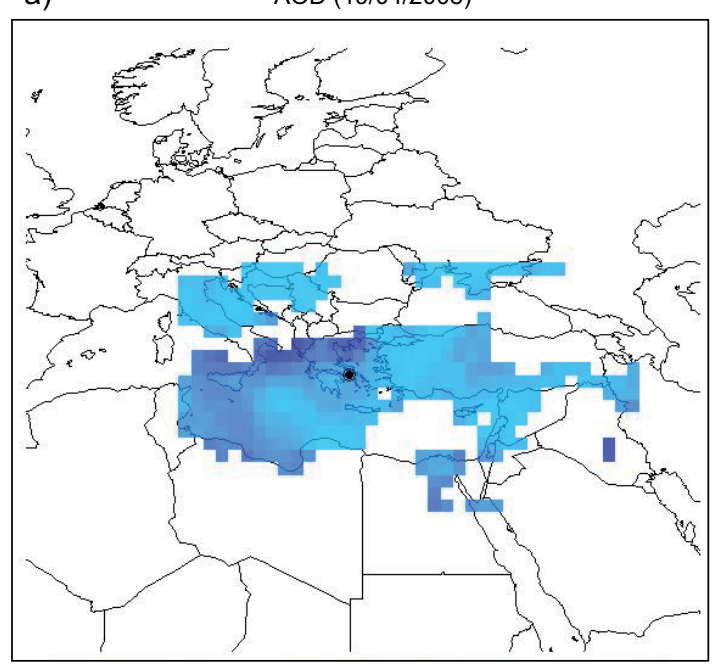

c)

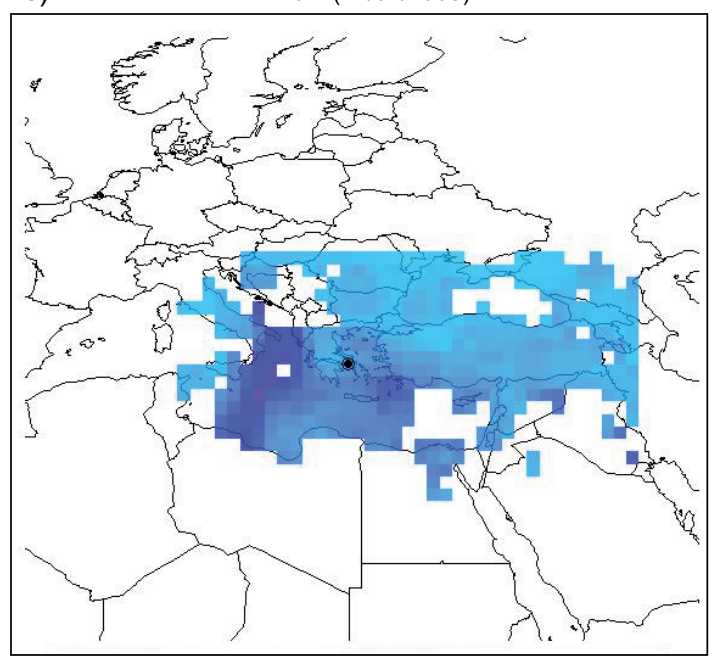

b)

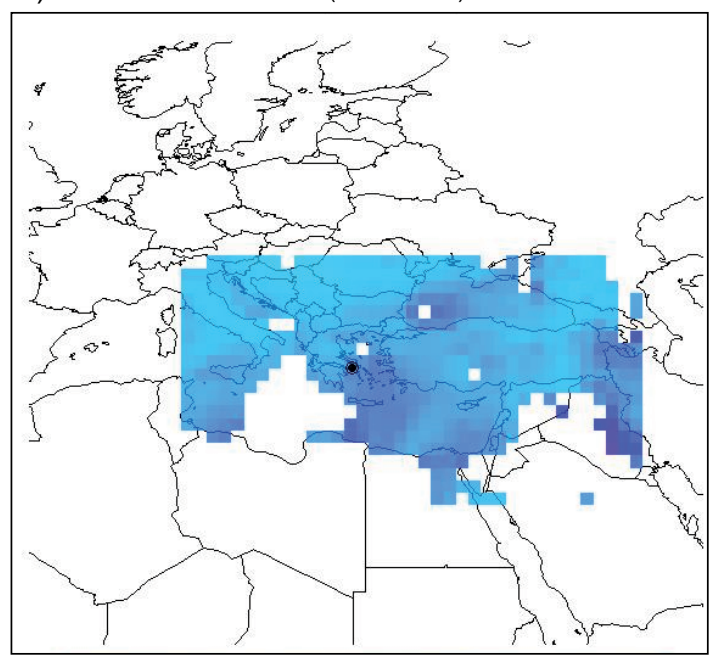

d)

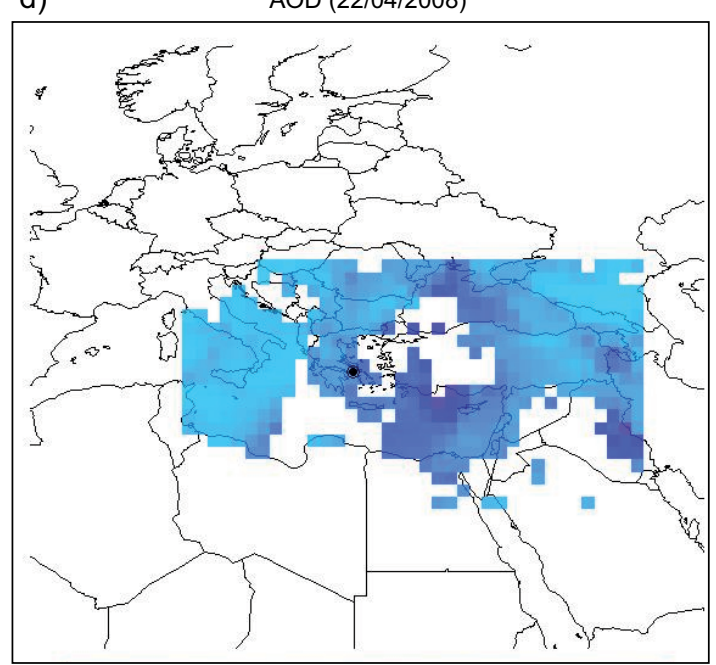

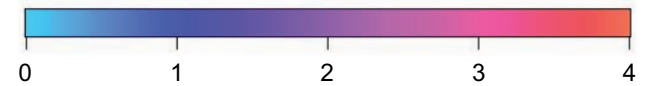

Fig. 10: Daily AOD observations of MODIS from 19/04/2008 to 22/04/2008.

detected by AOD measurements of MODIS shifting towards Turkey, Egypt and the Middle East (Fig $12 \mathrm{a}, \mathrm{b})$. The large high-pressure system, located over central Europe from 25/04/2008 to 26/04/2008 (Fig. 11b) produced a northern airflow (Fig. 11a), which enhanced further the transportation of dust from Greece to southern areas (Fig. 12c, d). In addition, this anticyclonic system blocked the pathway of a new depression approaching from the North Atlantic (Fig. 11b), preventing a possible third dust wave in Athens.
3.3 Variations of meteorological parameters - Air quality and thermal discomfort assessment.

Throughout the two studied dust waves, warm and dry air of North African origin was conveyed to the Greek region. Thus, air temperature at the Elefsis station was increased, whereas RH was strongly reduced (Fig. 13a). The decrease of wind speed, recorded during both dust aerosol events (Fig. 13b) favors the accumulation of particles possibly related with the observed drop in visibility (Fig. 13b). In addition, elevated wind speed levels, monitored after the two 
a)
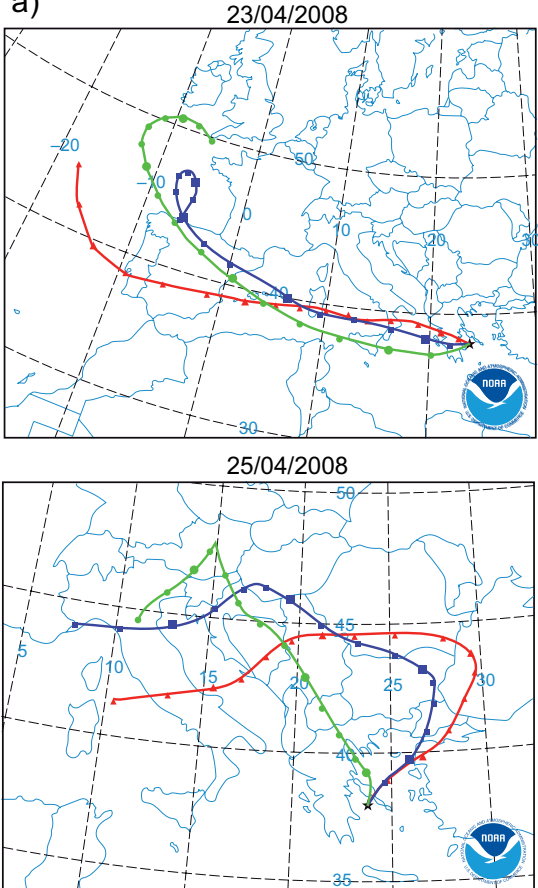

b)

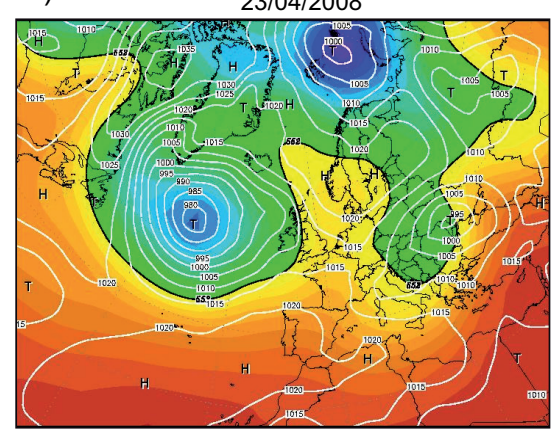

25/04/2008

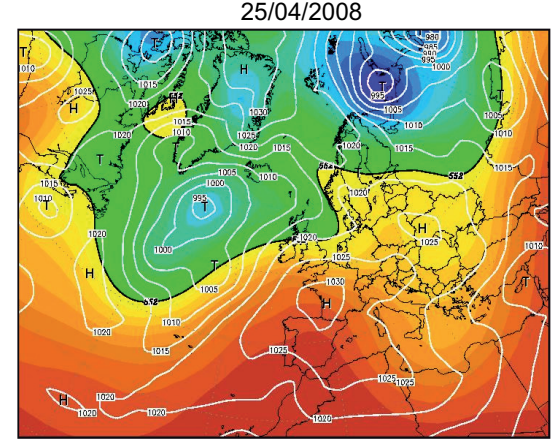

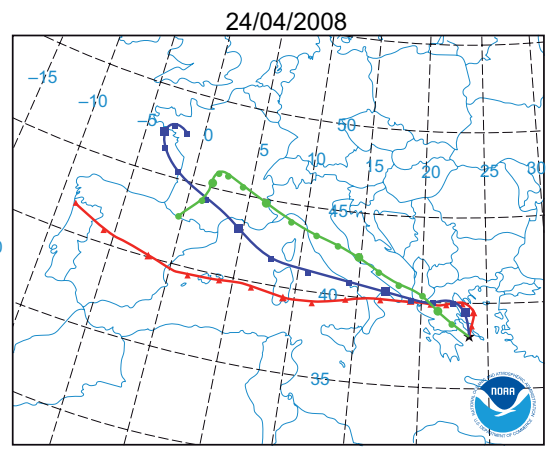

26/04/2008

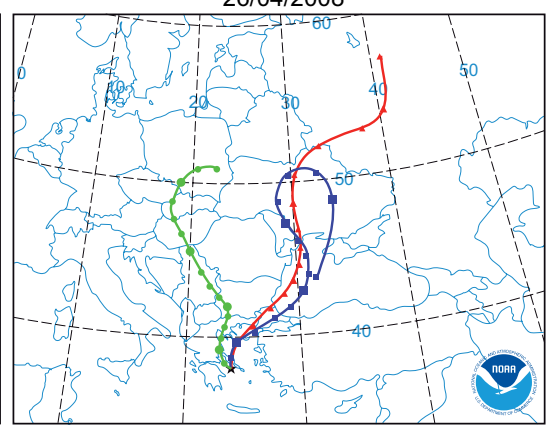

$24 / 04 / 2008$

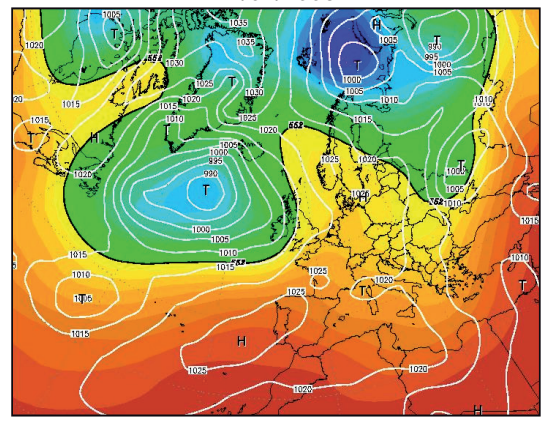

$26 / 04 / 2008$

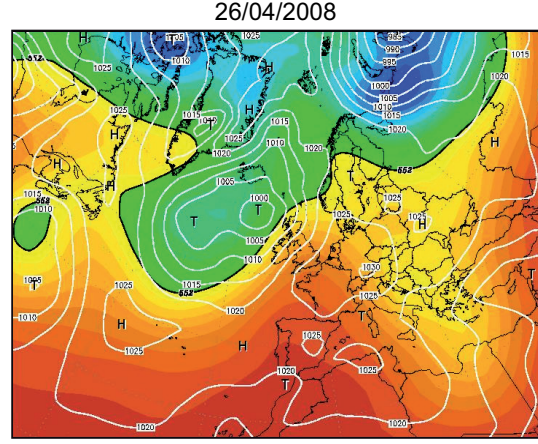

Fig. 11. Same as in Figure 3, but for the time interval 23/04/2008 - 26/04/2008. 
a)

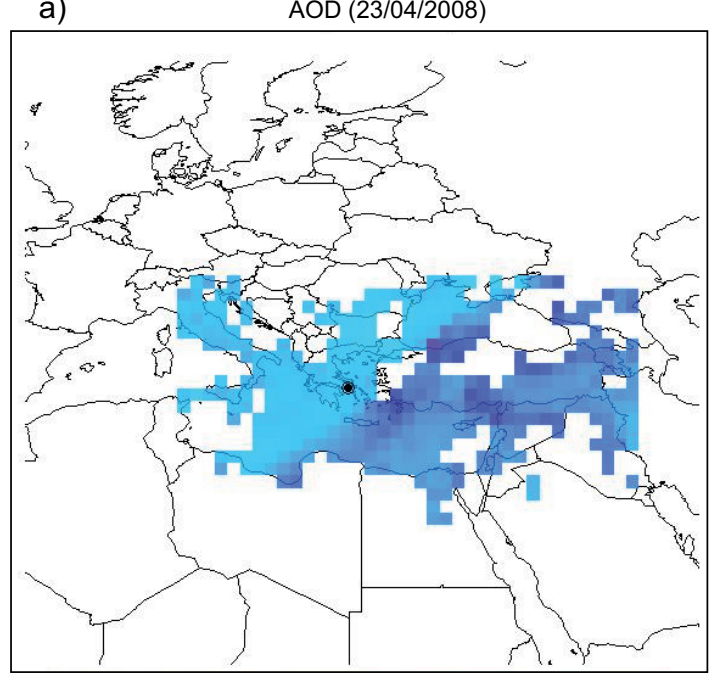

c)

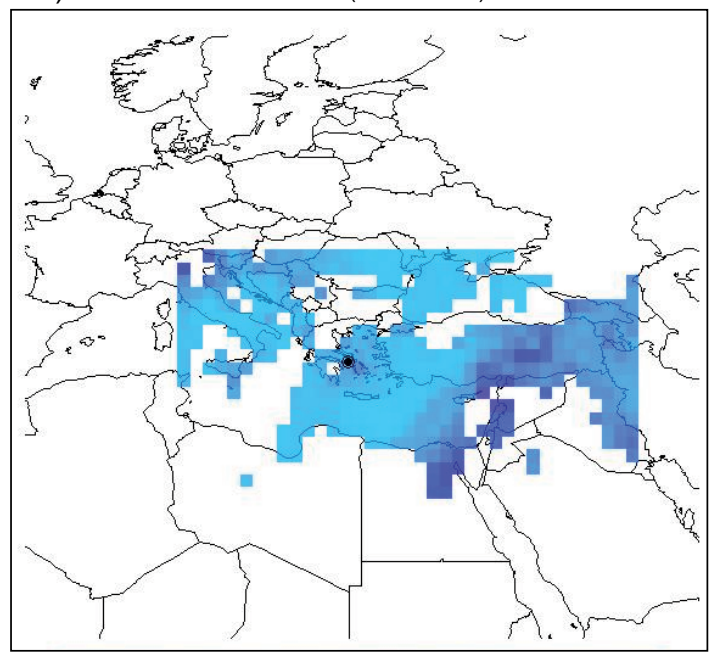

b)

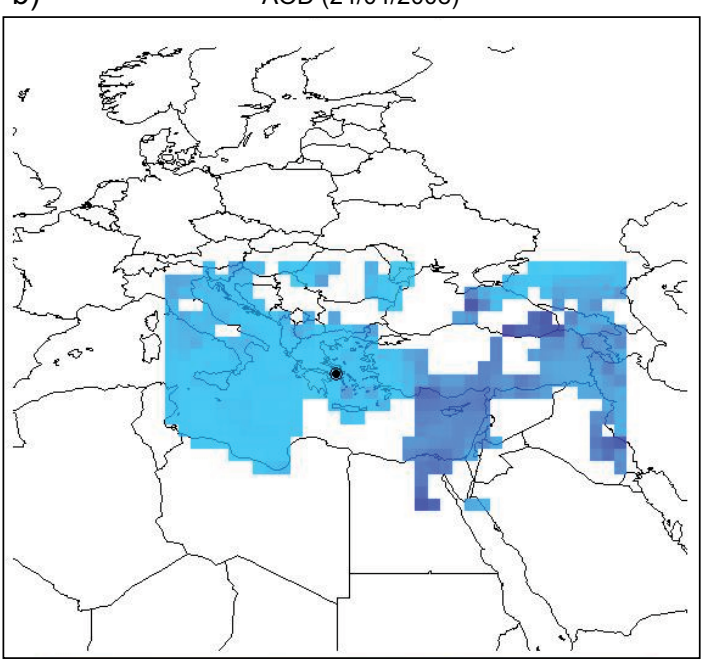

d)

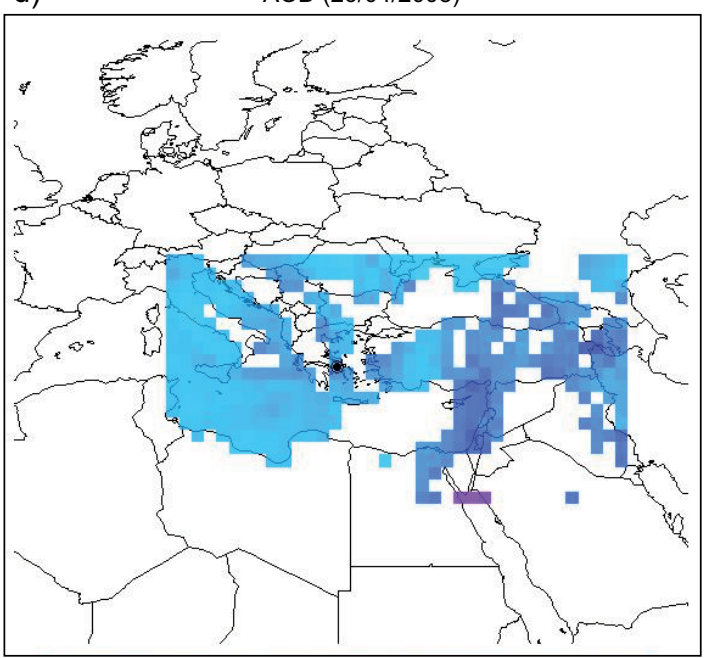

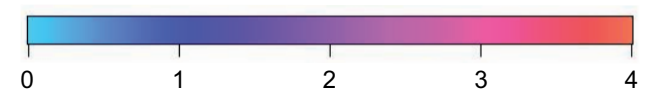

Fig. 12. Daily AOD observations of MODIS from 23/04/2008 to 26/04/2008.

dust invasions, are coherent with the corresponding long-range fast moving trajectories (Figs. 7a, 11a), indicating dust dispersion.

Daily average $\mathrm{PM}_{10}$ concentrations were strongly amplified during the two dust events, thus PI values for $\mathrm{PM}_{10}$ were classified in the upper boundaries of the moderate pollution category (Fig. 13c) according to Table I. After the passing of each dust wave, PI values for $\mathrm{PM}_{10}$ returned to the low pollution category $(\mathrm{PI}<50)$. On the contrary, $\mathrm{PI}$ values for $\mathrm{NO}_{2}$ remained in the low pollution category $(\mathrm{PI}<50)$ or in the good quality category $(\mathrm{PI}<25)$ during the whole studied period (Fig. 13c), thus low combustion emissions were suggested. Finally, despite the increase in temperature levels, DI stayed in the thermal comfort category $(<21)$ throughout the two dust events (Fig. 13c), thus no thermal stress for the population was indicated (Table II).

\section{Conclusions}

In this paper, a day-by-day analysis of a two-wave Saharan dust event affecting Athens, Greece was 
a)

- Temperature $\left({ }^{\circ} \mathrm{C}\right) \quad-\mathrm{RH}(\%)$

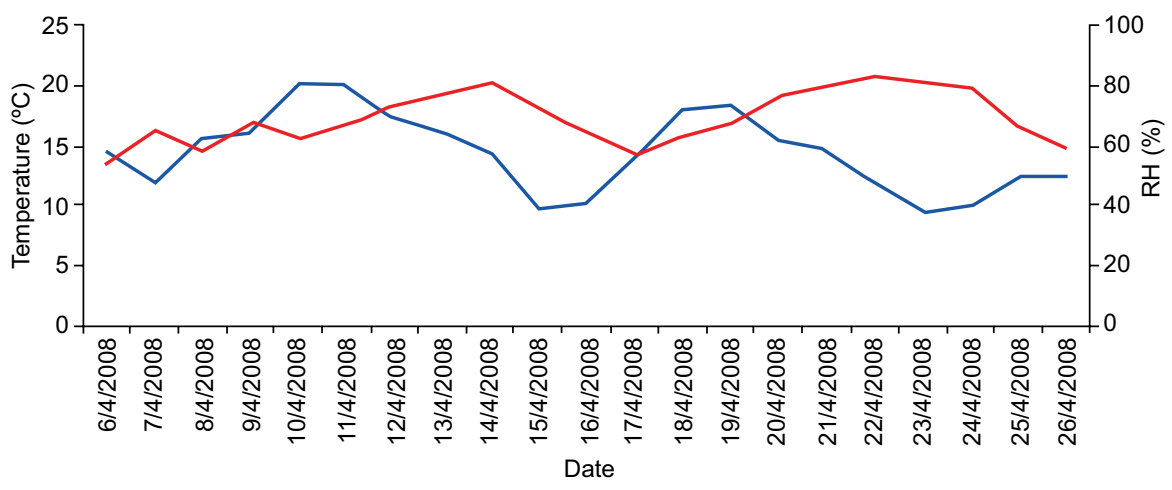

b)

Wind speed $(\mathrm{m} / \mathrm{sec}) \quad$ Visibility $(\mathrm{km})$

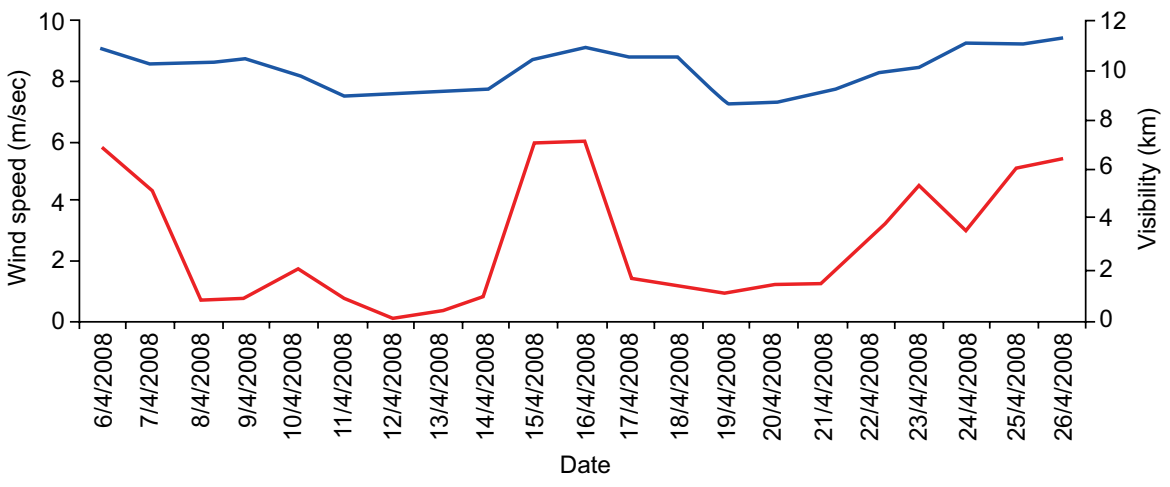

c)

$-\mathrm{Pl}\left(\mathrm{PM}_{10}\right)-\mathrm{PI}\left(\mathrm{NO}_{2}\right)-\mathrm{DI}$

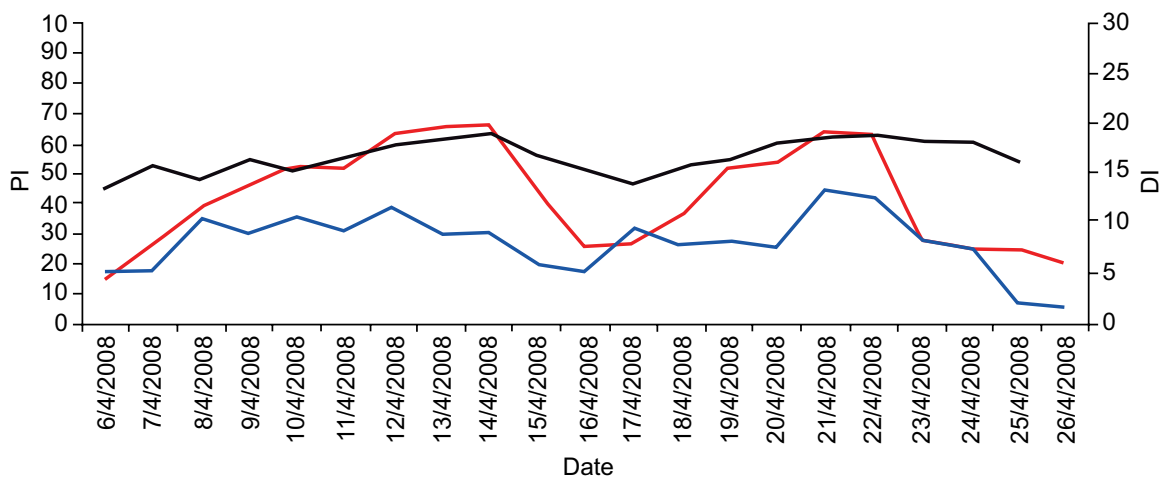

Fig. 13. (a) Daily average values of temperature (C) and RH (\%) at Elefsis. (b) Daily average values of wind speed $\left(\mathrm{m} \mathrm{sec}^{-1}\right)$ and visibility $(\mathrm{km})$ at Elefsis. (c) Daily PI values (for $\mathrm{PM}_{10}$ and $\mathrm{NO}_{2}$ ) at $\mathrm{AGP}$ and daily $\mathrm{DI}$ values at Elefsis.

attempted. Satellite daily AOD measurements were used, in order to follow the course of two dust plumes originated in North Africa and travelling through the eastern Mediterranean. The time intervals before and after each dust wave were also taken under consideration, aiming to identify the atmospheric circulation that generated the dust storm and also the clearing mechanisms that removed the African dust from the Athenian atmosphere. For this purpose, the AOD observations were combined with air mass trajectories and synoptic charts.

The source of the two dust plumes was isolated over Libya and Tunisia, where extreme daily AOD values were recorded. The transportation of dust 
in the Greek region, during both dust waves, was attributed to the advent of low-pressure systems from the Atlantic. The eastward movement of these barometric depressions across the Iberian Peninsula and western Mediterranean, induced S-SW airflows which transferred the dust aerosols from North Africa to Greece. The impact of both dust waves in Athens was interrupted by the prevalence of a strong NW air stream, which carried the particles eastwards through Turkey, Cyprus and the Middle East. After the second dust wave, the domination of an anticyclonic high-pressure system over central Europe ended the dust storm by blocking the pathway of a new depression incoming from the North Atlantic. During this dust event, air quality in Athens was downgraded, but no thermal discomfort occurred, according to the estimation of PI and DI indicators, respectively.

Satellite AOD observations clearly indicated the evolution and decline of this event and were coherent with ground based measurements of PM concentrations and meteorological parameters. In addition, the dust pathway was sufficiently explained based on the prevailing atmospheric circulation conditions. Nevertheless, this study could have been supplemented by an analysis of the chemical species included in the exogenous aerosol mass, providing valuable details on particle origin. Finally, the use of precipitation data, not available for this study, could have given information concerning the depletion of airborne aerosols due to wet deposition.

\section{Acknowledgments}

The authors would like to thank the European Union (EU) Air Quality Database for the provision of air pollution data, and also the National Centers for Environmental Information (NCEI) of NOAA, for providing the meteorological data. In addition, we would like to thank the MODIS science data support team for providing data via the Giovanni website (http:/giovanni.sci.gsfc.nasa.gov). The NCEP/ NCAR Reanalysis team and the German weather service are also gratefully acknowledged for providing the meteorological maps. Finally, the authors gratefully acknowledge the NOAA Air Resources Laboratory (ARL) for the provision of the HYSPLIT transport and dispersion model used in this publication.

\section{References}

Buchholz S., Junk J., Krein A., Heinemann G. and Hoffmann L., 2010. Air pollution characteristics associated with mesoscale atmospheric patterns in northwest continental Europe. Atmos. Environ. 44, 5183-5190. DOI: $10.1016 /$ j.atmosenv.2010.08.053

Bouchlaghem K., Nsom, B., Latrache, N., Kacem, H.H., 2009. Impact of Saharan dust on $\mathrm{PM}_{10}$ concentration in the Mediterranean Tunisian coasts. Atmos. Res. 92, 531-539.

DOI: 10.1016/j.atmosres.2009.02.009

Chen B.B., Sverdlik L.G., Imashev S.A., Solomon P.A., Lantz J., Schauer J.J., Shafer M.M., Artamonova M.S. and Carmichael G., 2013. Empirical relationship between particulate matter and aerosol optical depth over northern Tien-Shan, Central Asia. Air Qual. Atmos. Health. 6, 385-396.

DOI: $10.1007 / \mathrm{s} 11869-012-0192-5$

Ciardini V., Di Iorio T., Di Liberto L., Tirelli C., Casasanta G., Di Sarra A., Fiocco G., Fua D. and Cacciani M., 2012. Seasonal variability of tropospheric aerosols in Rome. Atmos. Res. 118, 205-214.

DOI: $10.1016 /$ j.atmosres.2012.06.026

De Meij A. and Lelieveld J., 2011. Evaluating aerosol optical properties observed by ground-based and satellite remote sensing over the Mediterranean and the Middle East in 2006. Atmos. Res. 99, 415-433.

DOI: 10.1016/j.atmosres.2010.11.005

Dimitriou K., Paschalidou A.K. and Kassomenos P.A., 2013. Assessing air quality with regards to its effects on human health in the European Union through air quality indices. Ecol. Ind. 27, 108-115.

DOI: $10.1016 /$ j.ecolind.2012.11.023

Dimitriou K., 2015. The dependence of PM size distribution from meteorology and local-regional contributions, in Valencia (Spain) - A CWT model approach. Aerosol Air Qual. Res. 15, 1979-1989.

DOI: 10.1016/j.ecolind.2012.11.023

Dimitriou K., Remoundaki E., Mantas E. and Kassomenos P., 2015. Spatial distribution of source areas of $\mathrm{PM}_{2.5}$ by Concentration Weighted Trajectory (CWT) model applied in $\mathrm{PM}_{2.5}$ concentration and composition data. Atmos. Environ. 116, 138-145.

DOI: 10.1016/j.atmosenv.2015.06.021

Giles B.D., Balafoutis C.H. and Maheras P., 1990. Too hot for comfort: The heatwaves in Greece in 1987 and 1988. Int. J. Biometeorol. 34, 98-104.

DOI: 10.1007/BF01093455 
Jiménez E., Linares C., Martínez D. and Díaz J., 2010. Role of Saharan dust in the relationship between particulate matter and short-term daily mortality among the elderly in Madrid (Spain). Sci. Tot. Environ. 408, 5729-5736. DOI: $10.1016 /$ j.scitotenv.2010.08.049

Kabatas B., Unal A., Pierce R.B., Kindap T. and Pozzoli, L., 2014. The contribution of Saharan dust in $\mathrm{PM}_{10}$ concentration levels in Anatolian Peninsula of Turkey. Sci. Tot. Environ. 488-489, 413-421.

DOI: $10.1016 /$ j.scitotenv.2013.12.045

Kaskaoutis D.G., Kambezidis H.D., Nastos P.T. and Kosmopoulos P.G., 2008. Study on an intense dust storm over Greece. Atmos. Environ. 42, 6884-6896.

DOI: 10.1016/j.atmosenv.2008.05.017

Kaskaoutis D.G., Nastos P.T., Kosmopoulos P.G. and Kambezidis H.D., 2012. Characterising the long-range transport mechanisms of different aerosol types over Athens, Greece during 2000-2005. Int. J. Climatol. 32: $1249-1270$.

DOI: $10.1002 /$ joc. 2357

Kassomenos P., Vardoulakis S., Chaloulakou A., Grivas G., Borge R. and Lumbreras J., 2012. Levels, sources and seasonality of coarse particles $\left(\mathrm{PM}_{10}-\mathrm{PM}_{2.5}\right)$ in three European capitals - Implications for particulate pollution control. Atmos. Environ. 54, 337-347.

DOI: $10.1016 /$ j.atmosenv.2012.02.051

Koçak M., Mihalopoulos N. and Kubilay N., 2007. Chemical composition of the fine and coarse fraction of aerosols in the northeastern Mediterranean. Atmos. Environ. 41, 7351-7368.

DOI: $10.1016 /$ j.atmosenv.2007.05.011

Kopanakis I., Eleftheriadis K., Mihalopoulos N., Lydakis-Simantiris N., Katsivela E., Pentari D., Zarmpas P. and Lazaridis M., 2012. Physico-chemical characteristics of particulate matter in the Eastern Mediterranean. Atmos. Res. 106, 93-107.

DOI: 10.1016/j.atmosres.2011.11.011

Kyrkilis G., Chaloulakou A. and Kassomenos P., 2007. Development of an aggregate Air Quality Index for an urban Mediterranean agglomeration: Relation to potential health effects. Environ. Intern. 33, 670-676. DOI: 10.1016/j.envint.2007.01.010

Lee S., Ho C-H., Lee Y.G., Choi H-J. and Song C-K., 2013. Influence of transboundary air pollutants from China on the high-PM10 episode in Seoul, Korea for the period October 16-20, 2008. Atmos. Environ. 77, 430-439.

DOI: $10.1016 /$ j.atmosenv.2013.05.006
Li L., Qian J., Ou C.-Q., Zhou Y-X., Guo C. and Guo Y., 2014. Spatial and temporal analysis of Air Pollution Index and its timescale-dependent relationship with meteorological factors in Guangzhou, China, 20012011. Environ. Pollut. 190, 75-81.

DOI: $10.1016 /$ j.envpol.2014.03.020

Malaguti A., Mircea M., La Torretta T.M.G., Telloli C., Petralia E., Stracquadanio M. and Berico M., 2015. chemical composition of fine and coarse aerosol particles in the central Mediterranean area during dust and non-dust conditions. Aerosol Air Qual. Res. 15, 410-425.

DOI: 10.4209/aaqr.2014.08.0172

Malone S., Stafoggia M., Faustini A., Gobbi G.P., Marconi A. and Forastiere F., 2011. Saharan dust and associations between particulate matter and daily mortality in Rome, Italy. Environ. Health. Perspect. 119, 1409-1414.

DOI: 10.12989/ehp.1003026.

Marconi M., Sferlazzo D.M., Becagli S., Bommarito C., Calzolai G., Chiari M., Di Sarra A., Ghedini C., Gómez-Amo J.L., Lucarelli F., Meloni D., Monteleone F., Nava S., Pace G., Piacentino S., Rugi F., Severi M., Traversi R. and Udisti R., 2014. Saharan dust aerosol over the central Mediterranean Sea: $\mathrm{PM}_{10}$ chemical composition and concentration versus optical columnar measurements. Atmos. Chem. Phys. 14, 2039-2054. DOI: $10.5194 /$ acp-14-2039-2014

Masmoudi M., Alfaro S.C. and Metwally M.E., 2015. A comparison of the physical properties of desert dust retrieved from the sunphotometer observation of major events in the Sahara, Sahel, and Arabian Peninsula. Atmos. Res. 158-159, 24-35.

DOI: 10.1016/j.atmosres.2015.02.005

Mavrakis A., Spanou A., Pantavou K., Katavoutas G., Theoharatos G., Christides A. and Verouti E., 2012. Biometeorological and air quality assessment in an industrialized area of eastern Mediterranean: The Thriassion Plain, Greece. Int. J. Biometeorol. 56, 737-747. DOI: 10.1007/s00484-011-0475-9

Minguillon M.C., Campos A.A., Cardenas B., Blanco S., Molina L.T. and Querol X., 2014. Mass concentration, composition and sources of fine and coarse particulate matter in Tijuana, Mexico, during Cal-Mex campaign. Atmos. Environ. 88, 320-329.

DOI: 10.1016/j.atmosenv.2013.09.032

Mitsakou C., Kallos G., Papantoniou N., Spyrou C., Solomos S., Astitha M. and Housiadas C., 2008. Saharan 
dust levels in Greece and received inhalation doses. Atmos. Chem. Phys. 8, 7181-7192.

DOI: $10.5194 /$ acp-8-7181-2008

Moroni B., Castellini S., Crocchianti S., Piazzalunga A., Fermo P., Scardazza F. and Cappelletti D., 2015. Ground-based measurements of long-range transported aerosol at the rural regional background site of Monte Martano (Central Italy). Atmos. Res. 155, 26-36. 10.1016/j.atmosres.2014.11.021

Murena F., 2004. Measuring air quality over large urban areas: development and application of an air pollution index at the urban area of Naples. Atmos. Environ. 38, 6195-6202. DOI: 10.1016/j.atmosenv.2004.07.023

Nastos P.T., 2012. Meteorological patterns associated with intense saharan dust outbreaks over Greece in winter. Adv. Meteorol. ID828301, 1-17.

DOI: $10.1155 / 2012 / 828301$

Papayannis A., Balis D., Amiridis V., Chourdakis G., Tsaknakis G., Zerefos C., Castanho A.D.A., Nickovic S., Kazadzis S. and Grabowski J., 2005. Measurements of Saharan dust aerosols over the Eastern Mediterranean using elastic backscatter-Raman lidar, spectrophotometric and satellite observations in the frame of the EARLINET project. Atmos. Chem. Phys. 5, 20652079. DOI: $10.5194 / \mathrm{acp}-5-2065-2005$

Papayannis A., Mamouri R.E., Amiridis V., Kazadzis S., Perez C., Tsaknakis G., Kokkalis P. and Baldasano J.M., 2009. Systematic lidar observations of Saharan dust layers over Athens, Greece in the frame of EARLINET project (2004-2006). Ann. Geophys. 27, 3611-3620. DOI: 10.1029/2007JD009028

Papayannis A., Mamouri R.E., Amiridis V., Remoundaki E., Tsaknakis G., Kokkalis P., Veselovskii I., Kolgotin A., Nenes A. and Fountoukis C., 2012. Optical-microphysical properties of Saharan dust aerosols and composition relationship using a multi wavelength Raman lidar, in situ sensors and modelling: A case study analysis. Atmos. Chem. Phys. 12, 4011-4032. DOI: $10.5194 /$ acp-12-4011-2012

Pateraki St., Assimakopoulos V.D., Maggos Th., Fameli K.M., Kotroni V. and Vasilakos Ch., 2013. Particulate matter pollution over a Mediterranean urban area. Sci. Tot. Env. 463-464, 508-524.

DOI: $10.1016 /$ j.scitotenv.2013.05.076
Pérez L., Tobías A., Querol X., Pey J., Alastuey A., Díaz J. and Sunyer J., 2012. Saharan dust, particulate matter and cause-specific mortality: A case-crossover study in Barcelona (Spain). Environ. International. 48, 150-155. DOI: 10.1016/j.envint.2012.07.001

Remoundaki E., Bourliva A., Kokkalis P., Mamouri R.E., Papayannis A., Grigoratos T., Samara C. and Tsezos M., 2011. $\mathrm{PM}_{10}$ composition during an intense Saharan dust transport event over Athens (Greece). Sci. Tot. Env. 409, 4361-4372.

DOI: 10.1016/j.scitotenv.2011.06.026

Sajani S.Z., Miglio R., Bonasoni P., Cristofanelli P., Marinoni A., Sartini C., Goldoni C.A., De Girolamo G. and Lauriola P., 2011. Saharan dust and daily mortality in Emilia-Romagna (Italy). Occup. Environ. Med. 68, 446-451.

DOI: $10.1136 /$ oem.2010.058156

Samoli E., Nastos P.T., Paliatsos A.G., Katsouyanni K. and Priftis K.N., 2011. Acute effects of air pollution on pediatric asthma exacerbation: Evidence of association and effect modification. Environ. Res. 111, 418-424. DOI: 10.1016/j.envres.2011.01.014

Sprovieri F., Bencardino M., Cofone F. and Pirrone N., 2011. Chemical composition of aerosol size fractions at a coastal site in southwestern Italy: Seasonal variability and transport influence. J. Air Waste Manage. Assoc. 61, 941-951.

DOI: $10.1016 /$ j.envres.2011.01.014.

Thom E.C., 1959. The discomfort index. Weatherwise. 12, 57-60. DOI: 10.1080/00431672.1959.9926960

Tobías A., Pérez L., Díaz J., Linares C., Pey J., Alastruey A. and Querol X., 2011. Short-term effects of particulate matter on total mortality during Saharan dust outbreaks: A case-crossover analysis in Madrid (Spain). Sci. Tot. Environ. 412-413, 386-389.

DOI: $10.1016 /$ j.scitotenv.2011.10.027

Varga G., Ujvari G. and Kovacs J., 2014. Spatiotemporal patterns of Saharan dust outbreaks in the Mediterranean basin. Aeol. Res. 15, 151-160.

DOI: 10.1016/j.aeolia.2014.06.005 